\title{
Turnover of histones and histone variants in postnatal rat brain: effects of alcohol exposure
}

\author{
Nadia Rachdaoui ${ }^{1}$, Ling Li ${ }^{2}$, Belinda Willard², Takhar Kasumov ${ }^{3}$, Stephen Previs ${ }^{4}$ and Dipak Sarkar ${ }^{*}$
}

\begin{abstract}
Background: Alcohol consumption during pregnancy is a significant public health problem and can result in a continuum of adverse outcomes to the fetus known as fetal alcohol spectrum disorders (FASD). Subjects with FASD show significant neurological deficits, ranging from microencephaly, neurobehavioral, and mental health problems to poor social adjustment and stress tolerance. Neurons are particularly sensitive to alcohol exposure. The neurotoxic action of alcohol, i.e., through ROS production, induces DNA damage and neuronal cell death by apoptosis. In addition, epigenetics, including DNA methylation, histone posttranslational modifications (PTMs), and non-coding RNA, play an important role in the neuropathology of FASD. However, little is known about the temporal dynamics and kinetics of histones and their PTMs in FASD.

Results: We examined the effects of postnatal alcohol exposure (PAE), an animal model of human third-trimester equivalent, on the kinetics of various histone proteins in two distinct brain regions, the frontal cortex, and the hypothalamus, using in vivo ${ }^{2} \mathrm{H}_{2} \mathrm{O}$-labeling combined with mass spectrometry-based proteomics. We show that histones have long half-lives that are in the order of days. We also show that H3.3 and H2Az histone variants have faster turnovers than canonical histones and that acetylated histones, in general, have a faster turnover than unmodified and methylated histones. Our work is the first to show that PAE induces a differential reduction in turnover rates of histones in both brain regions studied. These alterations in histone turnover were associated with increased DNA damage and decreased cell proliferation in postnatal rat brain.
\end{abstract}

Conclusion: Alterations in histone turnover might interfere with histone deposition and chromatin stability, resulting in deregulated cell-specific gene expression and therefore contribute to the development of the neurological disorders associated with FASD. Using in vivo ${ }^{2} \mathrm{H}_{2} \mathrm{O}$-labeling and mass spectrometry-based proteomics might help in the understanding of histone turnover following alcohol exposure and could be of great importance in enabling researchers to identify novel targets and/or biomarkers for the prevention and management of fetal alcohol spectrum disorders.

Keywords: Postnatal alcohol exposure, Histone, Turnover, Brain, Post-translational modifications, ${ }^{2} \mathrm{H}_{2} \mathrm{O}-$ labeling, Mass spectrometry

\footnotetext{
* Correspondence: sarkar@aesop.rutgers.edu

${ }^{1}$ Department of Animal Sciences, Rutgers Endocrine Research Program,

Rutgers, the State University of New Jersey, 67 Poultry Farm Lane, New

Brunswick, NJ 08901, USA

Full list of author information is available at the end of the article
} 


\section{Background}

In FASD, both structural and functional defects are produced in the brain [1-3]. Neurons are particularly sensitive to alcohol exposure during critical periods of brain development when neurons form intricate spatial connections and organizations [4]. Mechanisms such as apoptosis, inhibition of proliferation, migration, and differentiation have been implicated in the establishment of alcohol-mediated patterning defects [5, 6]. Animal studies have shown that the neurotoxic action of alcohol during the developmental period reduces the number of hippocampal neurons $[7,8]$, cortical neurons [9], cerebral granule and Purkinje neurons $[10,11]$, and hypothalamic neurons [12]. We showed that alcohol increases $\beta$ endorphin neuronal death by apoptosis and reduces expression of important neuronal genes such as Pomc gene and brain-derived neurotrophic factors (BDNF), which regulate neurogenesis and cell survival in the hypothalamus [12-15]. Accumulation of DNA damage in the absence of repair has been proposed as a key factor in the pathogenicity of alcohol exposure [16]. Alcohol metabolism produces reactive oxygen species (ROS) and acetaldehyde, which have been shown to cause oxidative DNA damage $[17,18]$ and induce the production of 7,8-dihydro-8-oxo-2'-deoxyguanosine (oxo8dG) DNA lesions $[19,20]$.

Recent implications of epigenetic mechanisms as mediators of alcohol's teratogenic effects on the fetus provided insights into the complex characteristics of FASD. The deleterious effects of alcohol during the prenatal and postnatal periods of development correlate with peak periods of epigenetic reprogramming $[21,22]$. The existence of such critical developmental periods of vulnerability to the adverse effects of alcohol prompted researchers to study the role of alterations in the epigenome during these early stages of brain development. Garro and colleagues [23] were the first to show that administration of ethanol to pregnant mice on gestation days 9 to 11 resulted in global hypomethylation of fetal DNA, due to a direct inhibitory effect of alcohol on DNMT(s) (DNA methytransferases). We have shown that fetal alcohol exposure (FAE) decreases protein and mRNA levels of histone activating marks (H3K4me3, Set7/9, acetylated H3K9, phosphorylated $\mathrm{H} 3 \mathrm{~S} 10$ ) while it increases the repressive marks (H3K9me2, G9a, Setdb1), DNA-methylating enzyme (Dnmt1), and the methyl-CpG binding protein (MeCP2) in the hypothalamus [15, 24, 25]. As DNA damage and repair processes are most likely to play an important role in the alcohol-mediated neurotoxicity in FASD, histone proteins, particularly histone variants have also been shown to play a critical role in these repair processes. For example, deletion of $\mathrm{H} 2 \mathrm{Ax}$ or mutation of its Ser139 impairs the recruitment of DNA damage repair proteins, such as BRCA1 and 53BP1 [26, 27]. Most importantly, a HIRA-mediated H3.3 deposition in the DNA damage pathway is also crucial to the maintenance of chromatin integrity and the restoration of the transcriptional activity upon completion of DNA damage repair [28]. Therefore, the interplay between histone variants and chromatin remodeling and accessibility of DNA repair machinery suggests the importance of a sustained availability of histone molecules to ensure that the DNA lesions are faithfully repaired and transcription is resumed for cell function recovery.

Although histone posttranslational modifications (PTM) have been extensively studied in the context of FASD, changes in histone turnover remain unexplored. Herein, we have examined whether alcohol exposure alters histone protein turnover. Previous studies used ${ }^{14} \mathrm{C}$ - and ${ }^{3} \mathrm{H}$-radiolabeled amino acids [29], which are complicated in vivo, especially when the proteins of interest have long halflives. We previously demonstrated that labeled water (e.g., ${ }^{2} \mathrm{H}$ ) offers advantages in cases where protein synthesis is measured over long periods in free-living animals [30]. It is relatively straightforward to administer labeled water via the drinking bottles; the body will then rapidly generate ${ }^{2} \mathrm{H}$-labeled amino acids [30-32]. We took advantage of the ${ }^{2} \mathrm{H}$-water labeling method to circumvent some obvious problems that are associated with administering a tracer to newborn animals. Quantification of protein labeling is done via standard LC-MS instrumentation generally used in proteomic analyses [31]. Specifically, we investigated the effects of postnatal alcohol exposure (PAE) on the turnover of histone molecules and contrasted two important regions of rat brain, the frontal cortex and the hypothalamus.

\section{Methods}

\section{Animal procedures}

Adult Sprague Dawley rats were purchased from Charles River (Wilmington, MA) and maintained in a controlled environment with a 12-h light/dark cycle at a constant temperature $\left(22{ }^{\circ} \mathrm{C}\right)$. Adult female Sprague-Dawley rats were bred at 2 months of age in our vivarium. At postnatal day 2, rat pups of both sexes were either fed a milk formula containing $11.34 \%$ of ethanol yielding a daily ethanol dose of $2.5 \mathrm{~g} / \mathrm{kg}$ (alcohol-fed, AF) (Bio-Serv, Frenchtown, NJ) or an isocaloric liquid control diet (pair-fed, PF) (Bio-Serv) in which the alcohol calories were replaced by maltose-dextrin. Feedings were conducted at 1000 and $1200 \mathrm{~h}$ from postnatal day 2 until postnatal day 6 (PD2-PD6). In a preliminary study, we validated the use of $\mathrm{PF}$ as control group by comparing the biological data (BrdU incorporation and $\gamma \mathrm{H} 2 \mathrm{~A}$ as DNA damage marker) of PF group with ad libitum fed group (AD). The data in Additional file 1: Figure S2 and Additional file 2: Figure $\mathrm{S} 3$ shows that the PF and $\mathrm{AD}$ 
data are similar $(\gamma \mathrm{H} 2 \mathrm{AX}$ foci/mm, AD-265 \pm 46, PF$327 \pm 58, n=4-6 ; p>0.05$; $\mathrm{BrdU}^{+}$cells $/ \mathrm{mm}^{2}$, AD$1970 \pm 173$, PF-1775 $\pm 74, n=4 ; p>0.05)$. Hence, we only used PF group as a control group for alcohol treatment. For isotope tracer labeling and proteomic studies, on day 1 of feeding, rat pups (PF and $\mathrm{AF}$ ) received an intraperitoneal bolus injection of ${ }^{2} \mathrm{H}_{2} \mathrm{O}$ as normal saline and were then fed a milk diet that was enriched with $5 \%$ ${ }^{2} \mathrm{H}_{2} \mathrm{O}$ to ensure continuous precursor labeling [30,33]. Note that the use of the stable isotope $\left({ }^{2} \mathrm{H}\right)$ labeled water represents an adaptation of studies that previously relied on radioactive $\left({ }^{3} \mathrm{H}\right)$ labeled water [34]. In some experiments, pups from each experimental group were subcutaneously injected with the free radical spin trap $\alpha$ phenyl-N-tert-butyl nitrone (PBN) at $100 \mathrm{mg} / \mathrm{kg}$ before the morning feeding to investigate the role of ROS production in the effects of PAE on histone turnover. After each feeding, the pups were immediately returned to the litter. In some pups, blood alcohol concentration (BAC) was measured in trunk blood $1 \mathrm{~h}$ after the last ethanol feeding. Feeding $11.34 \% v / v$ ethanol increases BAC level to $\sim 0.2 \mathrm{~g} / \mathrm{dl}$, which is considered to be a moderate BAC. Feeding trials ran for a total of 5 days after which animals were euthanized and samples were quick-frozen. Note that samples were also collected from a subgroup of control animals, which were fed ad lib, and not given any tracer; samples from this group guide the analyses and background corrections. The need for such baseline samples is well known in tracer studies; since stable isotopes are naturally occurring, they generate a background signal that needs to be subtracted from experimental samples [35]. Animal care was performed in accordance with institutional guidelines and complied with National Institutes of Health policy.

\section{Acid extraction of histone}

Brains were collected on PD6 and mediobasal hypothalamus $(\mathrm{MBH})$ and frontal cortex was dissected. The frontal cortex was defined as the tissue extending from the frontal pole caudally to the bregma $3 \mathrm{~mm}$ in the pups (from figure 47 to figure 50) [36]. The hypothalamus was sectioned from the posterior portion of the optic chiasm until the end of the mediobasal hypothalamus, from figure 55 to figure 59 , according to Ramavhandra and Subrananian [36]. Histones were acid extracted as previously described with some modifications $[37,38]$. Briefly, dissected brain tissues were homogenized on ice in Triton Extraction Buffer (TEB: PBS containing $0.5 \%$ Triton X $100(v / v)$, protease inhibitors cocktail, and $5 \mathrm{mM}$ sodium butyrate) at $100 \mathrm{mg} / \mathrm{ml}$ using a tight-fitting glass Dounce homogenizer by applying 20 strokes and kept on ice for 5 to $10 \mathrm{~min}$. Samples were then centrifuged at $2000 \mathrm{rpm}$ for $10 \mathrm{~min}$ at $4{ }^{\circ} \mathrm{C}$. The supernatants were discarded, and the nuclear pellets are washed in half the volume of TEB and centrifuged as above. Histones are then acid extracted in $200 \mu \mathrm{l}$ of 0.4 $\mathrm{N} \mathrm{H}_{2} \mathrm{SO}_{4}$ and incubated overnight at $4{ }^{\circ} \mathrm{C}$ [36], then centrifuged at $14.000 \mathrm{~g}$ for $15 \mathrm{~min}$ at $4{ }^{\circ} \mathrm{C}$ and supernatant transferred to a clean $5 \mathrm{ml}$ tube. Two milliliters of cold acetone is then added and incubated at $-20{ }^{\circ} \mathrm{C}$ overnight to precipitate histones. Histones are then collected by centrifugation at $14,000 \mathrm{~g}$ for $15 \mathrm{~min}$, washed again with acetone then air dried, and resuspended in sterile deionized water. Protein concentration was measured using Bradford assay, and samples were stored at $-20{ }^{\circ} \mathrm{C}$ until further analysis.

\section{Preparation of histone samples for proteomics analysis}

Extracted histones were prepared for proteomic analyses as described by [39], with some modifications. Briefly, histones were first derivatized with propionic acid to block unmodified lysines. Briefly, $30 \mu \mathrm{g}$ of acid-extracted histones were dried down in a SpeedVac, then were dissolved in $15 \mu \mathrm{l} 0.1 \mathrm{M}$ ammonium bicarbonate solution and $10 \mu \mathrm{l}$ of deionized water. The $\mathrm{pH}$ of the samples was adjusted to 8 using concentrated ammonium hydroxide solution and reacted with $20 \mu \mathrm{l}$ of freshly prepared propionic anhydride/2-propanol solution (1:3 $v / v)$. The solution was immediately neutralized with $6 \mu \mathrm{l}$ of concentrated ammonium hydroxide $(12 \mathrm{~N})$. If needed, the $\mathrm{pH}$ of the solution was adjusted to 8 using additional concentrated ammonium hydroxide. Samples were incubated at $37{ }^{\circ} \mathrm{C}$ for $15 \mathrm{~min}$. To remove solvent, the samples were evaporated for $30 \mathrm{~min}$ in a SpeedVac. To perform an additional round of propionylation, samples were dissolved in $20 \mu \mathrm{l}$ of deionized water; $\mathrm{pH}$ of the samples were adjusted to 8 using concentrated ammonium hydroxide and propionylated with anhydride/2propanol solution $(1: 3 v / v)$. Dried samples were then dissolved in $50 \mu \mathrm{l}$ of $0.1 \mathrm{M}$ ammonium bicarbonate; the $\mathrm{pH}$ was adjusted to 8 using concentrated ammonium hydroxide as needed. Histones were digested with $15 \mu \mathrm{l}$ of $100 \mathrm{ng} / \mathrm{mL}$ sequencing grade Tripsin (Promega, Madison, WI) at $37{ }^{\circ} \mathrm{C}$ for $6 \mathrm{~h}$. To stop the digestion, $5 \mu \mathrm{l}$ of acetic acid was added to each sample and then concentrated to $<10 \mu \mathrm{l}$ using a SpeedVac. After adjusting the $\mathrm{pH}$ to 8 , propionylation was repeated twice. The volume of each sample was adjusted to $20 \mu$ l using $5 \%$ trifluoroacetic acid, and $10 \mu \mathrm{l}$ aliquot was purified and desalted using a C18 Ziptip (Millipore, Darmstadt, Germany). Eluted samples were dried in a SpeedVac and reconstituted in $30 \mu \mathrm{l}$ of $1 \%$ acetic acid for LC-MS analysis.

\section{LC-MS/MS analysis of proteolytic peptides}

Proteomic analysis was carried out by nano-flow LCMS/MS with a Thermo Acclaim PepMap RSLC C18 nano-column $(150 \mathrm{~mm} \times 75 \mu \mathrm{m}, 2 \mu \mathrm{m}, 100 \AA)$ using mobile phase A and B (1\% formic acid in water and 
$0.1 \%$ formic acid in acetonitrile, respectively). Tandem mass spectrometry was performed on a Thermo LTQ Oribtrap Elite mass spectrometer (Thermo Scientific, Bremen, Germany) in positive ion mode. Each full scan MS at a resolution of $60,000($ at $400 \mathrm{~m} / \mathrm{z}$ ) was followed by 15 collision induced dissociation (CID) MS/MS (or MS2) scans. Dynamic exclusion was triggered by three consecutive selections within $30 \mathrm{~s}$ and last for $90 \mathrm{~s}$.

For protein identification, all of the CID spectra obtained from the mass spectrometer were searched using Sequest which is integrated in Thermo Proteome Discoverer software (Version 1.4) against histone protein extracted from National Center for Biotechnology Information (NCBI) Rattus norvegicus reference sequence database. The mass tolerances of the parent and product ions were set at $10 \mathrm{ppm}$ and $1.0 \mathrm{Th}$, respectively. Trypsin was used as protease with two missed cleavages allowed. Propionylation of $\mathrm{K}$ and $\mathrm{N}$-terminus residues were set as fixed modifications. A summary of the histone peptides used to determine histone turnover is presented in Table 1.

To quantify $2 \mathrm{H}$ incorporation into histones, we manually integrated the areas under each mass isotopomer of tryptic peptides identified in protein database searches. Peptides that cannot be assigned to unique proteins are excluded. The mass isotopic distribution for all selected

Table 1 List of histone peptides identified by LC-MS/MS and used to calculate turnover of unmodified and modified histone proteins

\begin{tabular}{|c|c|}
\hline Histone & Peptide sequence \\
\hline H2Aun & $\mathbf{p r v} \mathbf{v} T I A Q G G V L P N I Q A V L L P \mathbf{k}_{\mathbf{p r}} \mathbf{k}_{\mathbf{p r}}{ }^{\top E S H H \mathbf{k}}$ \\
\hline H2AK120meK126ac & 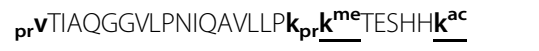 \\
\hline H2Bun & 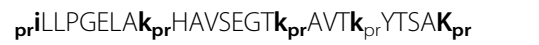 \\
\hline H2BK9ac & 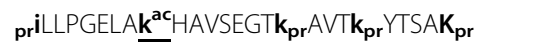 \\
\hline H3un & 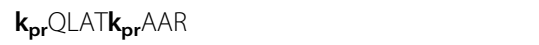 \\
\hline H3K1ac & $\underline{\mathbf{k}^{\text {ac }}}$ QLATk $\mathbf{k}_{\mathbf{r}} \mathrm{AAR}$ \\
\hline H3K9 & $\mathbf{k}_{\mathbf{p r}} \mathrm{STGG} \mathbf{k}_{\mathbf{p r}} \mathrm{APR}$ \\
\hline H3K9me2 & $\underline{\mathbf{k}}^{\mathbf{m e} 2} \mathrm{STGG} \mathbf{k}_{\mathbf{p r}} \mathrm{APR}$ \\
\hline H3K9me3 & $\underline{\mathbf{k}}^{\mathbf{m e} 3} \mathrm{STGG} \mathbf{k}_{\mathbf{p r}} \mathrm{APR}$ \\
\hline H3K9ac & $\underline{\mathbf{k}^{\mathbf{a c}} S T G G \mathbf{k} A P R}$ \\
\hline H4un & $\underline{\mathbf{p r}} \mathbf{g} \mathbf{k}_{\mathbf{p r}} G G \mathbf{k}_{\mathbf{p r}} G L G \mathbf{k}_{\mathbf{p r}} G G A \mathbf{k}_{\mathbf{p r}} R$ \\
\hline H4K5acK9acK13ac & 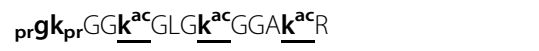 \\
\hline $\mathrm{H} 1$ & 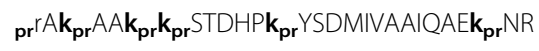 \\
\hline $\mathrm{H} 1.1$ & 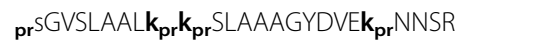 \\
\hline $\mathrm{H} 1.4$ & 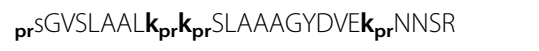 \\
\hline $\mathrm{H} 1.5$ & $\mathbf{k}_{\mathbf{p r}}$ ATGPPVSELIT $\mathbf{k}_{\mathbf{p r}}$ AVSASk $\mathbf{k}_{\mathbf{p r}}$ ER \\
\hline H3.3 & $\mathbf{k}_{\mathbf{p r}}$ SAPSTGGVk $\mathbf{k}_{\mathbf{p r}} \mathbf{k}_{\mathbf{p r}}$ PHR \\
\hline $\mathrm{H} 2 \mathrm{Ax}$ & $\mathbf{k}_{\mathbf{p r}}$ GHYAER \\
\hline $\mathrm{H} 2 \mathrm{Az}$ & 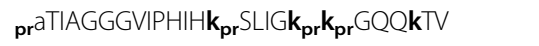 \\
\hline
\end{tabular}

All N-termini and all Lysine residues were propionylated by chemical derivatization. me methyl, ac acethyl, pr propionyl amide peptides are quantified as a function of time; the fractional synthesis rate (FSR) is then calculated from the shift in the distribution profile [30,31].

\section{GC-MS analysis of plasma water labeling}

The ${ }^{2} \mathrm{H}$-labeling of plasma water was determined using GC-MS following the exchange of label with acetone [40]; under alkaline conditions, the ${ }^{2} \mathrm{H}$ that is present in water will exchange with hydrogen that is bound to acetone, the enrichment of acetone is then quantified. Briefly, samples are prepared by incubating $5 \mu \mathrm{L}$ of plasma or known standards in a $2 \mathrm{ml}$ glass screw-top GC vial at room temperature for $4 \mathrm{~h}$ with $2 \mu \mathrm{L} 10 \mathrm{~N} \mathrm{NaOH}$ (Fisher Scientific, Maltham, MA) and $5 \mu \mathrm{L}$ of acetone (Sigma, St. Louis, MO). The GC-MS is programmed to inject $5 \mu \mathrm{L}$ of headspace gas from the GC vial in a splitless mode using an isothermal run (Agilent 5973 MS coupled to a 6890 GC oven fitted with an Agilent DB-5MS column), the mass spectrometer is operated in selected ion monitoring (electron impact ionization, $\mathrm{m} / \mathrm{z} 58$ and 59, $10 \mathrm{~ms}$ dwell time per ion).

\section{Data analysis and calculation of protein kinetics}

As noted above, the first step in the LC/MS analyses is to identify the peptide species. This is done from the accurate mass determination and the fragmentation spectrum. Examples of histone peptide spectra are shown in Additional file 3: Figure S1, and a summary of the histone peptides identified and used for the determination of histone turnover is listed in Table 1 . In the case of the peptide vTIAQGGVLPNIQAVLLPkkTESHHk, which is derived from hypothalamic histone $\mathrm{H} 2 \mathrm{~A}$, we observed a signal at 1001.57 a.m.u. with a charge state of $3+$; this reflects propionyl modifications from the chemical derivatization which are observed at the N-terminal, K119, K120, and K126 residues. The second step in the LC/MS analyses is to determine if the mass isotopomer distribution in a spectrum is shifted from the respective control samples. For example, all proteins have a natural isotopic distribution; they exist as a mixture of slightly different molecular weights. This results from the fact that the various elemental building blocks are not made of homogenous pools, e.g., carbon is present in the body as both ${ }^{12} \mathrm{C}$ and ${ }^{13} \mathrm{C}$, hydrogen is present as both ${ }^{1} \mathrm{H}$ and ${ }^{2} \mathrm{H}$, etc. A standard approach to better visualize the isotopic distribution of a target analyte involves normalizing the abundance of the heavy isotopes to what is referred to as the "M0" or "monoisotopic" peak, i.e., the analyte which contains only ${ }^{12} \mathrm{C},{ }^{1} \mathrm{H},{ }^{14} \mathrm{~N},{ }^{16} \mathrm{O}$, etc. Therefore, in the case of peptide vTIAQGGVLPNIQAVLLPkkTESHHk, we divide each signal by that of the M0 signal (an example of this is shown in Fig. 1).

Isotopic distributions are determined after correction for natural background labeling. 
VTIAQGGVLPNIQAVLLPkkTESHHk

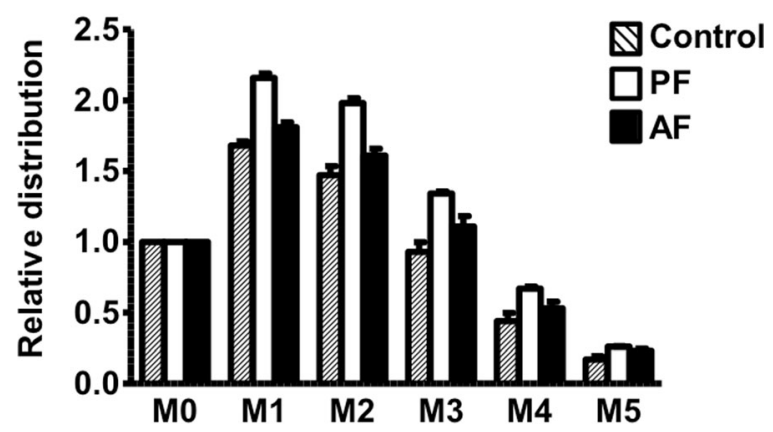

Fig. 1 Mass isotopomer distribution profiles of a tryptic peptide from histone H2A. LC-MS analyses were used to determine the isotope profile of the peptide VTIAQGGVLPNIQAVLLPkk TESHHk ; the intensity of the MO peak (i.e., monoisotopic, m/z 1001.57 with a charge state of 3+) was used to normalize the intensities of the other mass isotopomers. Samples were obtained from control animals (i.e., who did not receive any tracer, shaded bars) and from animals in the respective pair-fed (PF, open bars) and alcohol-fed (AF, solid bars) groups following 5 days of ${ }^{2} \mathrm{H}_{2} \mathrm{O}$ exposure. The mass isotopomer profile in PF animals reflects a more active turnover (i.e., incorporation of ${ }^{2} \mathrm{H}$ ) as compared to AF animals (which more closely resemble the control animals, representing a reduced turnover with limited incorporation of ${ }^{2} \mathrm{H}$ ). Data are shown as the mean \pm sem, $n=3-4$ animals per group

The molar percent enrichment (MPE) of a given peptide is calculated as:

$$
\begin{aligned}
M P E M i= & {[\text { Area of Mi/Sum of areas of allisotopomers }] } \\
& \times 100 \% .
\end{aligned}
$$

The total labeling of a peptide is calculated as:

$$
\text { Total } M P E=M P E_{M 1 x 1}+M P E_{M 2 x 2}+\ldots \ldots+M P E_{M i x i}
$$

Since our studies collected samples at a single point in time, we estimated the fractional synthesis rate (FSR) of a given protein using the equation:

$$
\operatorname{FSR}(\% / h)=\text { slope of peptide labeling } /\left(E_{\text {water }} \times N\right)
$$

where "slope of peptide labeling" is the rate of the increase in ${ }^{2} \mathrm{H}$-labeling of the product during ${ }^{2} \mathrm{H}_{2} \mathrm{O}$ administration and $E_{\text {water }}$ is the steady state enrichment of total body water. $N$ is the asymptotic constant number of ${ }^{2} \mathrm{H}$ incorporated into an analyzed product, which is calculated based on the number of exchangeable $\mathrm{H}$ atoms at $\mathrm{C}-\mathrm{H}$ sites of a peptide sequence [30, 33].

\section{Western blot analysis of total histones}

Total histone levels were determined by western blot analysis. Whole brain tissue samples were processed for acid extraction of histones and quantification using the Bradford Assay (Bio-Rad Laboratories). Eight to ten micrograms of total histones were run on a $15 \%$ SDS PAGE and transferred to PVDF membrane. Membranes were blocked with 5\% nonfat dry milk in TBST at room temperature for $2 \mathrm{~h}$ then incubated with different primary antibodies for histone proteins at $4{ }^{\circ} \mathrm{C}$ overnight. The primary antibodies used were rabbit anti-H2A (cat\# 2578, 1:1000, Cell Signaling) and rabbit anti H3 (cat\# ab1791,1:1000), rabbit anti-H3.3 (cat\# ab62642, 1:1000) and rabbit anti-H2Az (cat\# ab4174, 1:1000) from Abcam. We also used rabbit anti-H4 (cat\# 07-108, 1/1000, Millipore) and mouse anti- $\beta$-actin (cat\# CP01-1EA,1:5000, Calbiochem). Membranes were then washed in TBS-T and incubated with the appropriate secondary antibodies conjugated to a horseradish peroxidase followed by chemilumenescence detection using ECL reagents (Thermo Fisher Scientific).

\section{Immunofluorescence staining for $\mathrm{\gamma H} 2 \mathrm{Ax}$}

Twenty millimeters of frozen sections from PF and AF, prefrontal cortex (bregma 4.7 to $3.2 \mathrm{~mm}$ ), and hypothalamic arcuate nucleus (ARC) (bregma -1.8 to -4.3 ) were used for these studies. Sections were fixed with $4 \%$ paraformaldehyde and stained overnight at $4{ }^{\circ} \mathrm{C}$ with mouse anti- $\gamma \mathrm{H} 2 \mathrm{Ax}$ (EMD Millipore, Billerica, MA; 1/250) antibodies. The secondary antibody used was Alexa Fluor 594 donkey anti-mouse (Abcam, Cambridge, MA; 1/ 500). Sections were mounted with a mounting medium containing 4',6-diamidino-2-phenylindole (DAPI) to counterstain nuclei (Invitrogen, Waltham, MA). $\gamma \mathrm{H} 2 \mathrm{Ax}$ foci were quantified using ITCN (Image-based Tool for Counting Nuclei for ImageJ, NIH, Bethesda).

\section{Detection of 8-hydroxy 2 deoxyguanosine (8-OHdG)}

A competitive ELISA for 8-OHdG was performed using a commercial 8-OHdG ELISA kit (Abcam, Cambridge, MA), following the manufacturer's instructions. The DNA was purified from frontal cortex and hypothalamus using the DNeasy Blood and Tissue Purification kit (Qiagin, Germantown, MD). DNA quantity and purity were determined using NanoDrop-1000 version 3.7 (Thermo Scientific, Maltham, MA). Enzymatic digestion was performed using nuclease P1 ( $\mathrm{pH}$ 5.3; Sigma, St. Louis, $\mathrm{MO})$ at $50{ }^{\circ} \mathrm{C}$ for $1 \mathrm{~h}$ and treated with alkaline phosphatase ( $\mathrm{pH}$ 8.5; New England BioLabs, Ipswich, MA) at $37{ }^{\circ} \mathrm{C}$ for $30 \mathrm{~min}$. Samples were boiled for $10 \mathrm{~min}$ and placed on ice for $5 \mathrm{~min}$. DNA hydrolysates were analyzed by ELISA, following the manufacturer's instructions, and OD was measured at $450 \mathrm{~nm}$ using a plate reader (Thermo Scientific, Maltham, MA), and the level of 8-OHdG was determined for each sample from a standard curve.

\section{BrdU incorporation assay in vivo}

In vivo bromodeoxyuridine (BrdU) incorporation was performed to analyze cell proliferation in the brain of rat pups. BrdU (Sigma, St. Louis, MO) (50 mg/kg) was 
subcutaneously administrated everyday during ethanol feeding from PD4 to PD6 before sacrifice of pups. The brains were then collected and snap frozen in dry ice. Frozen brains from PF and AF from prefrontal cortex (bregma 4.7 to $3.2 \mathrm{~mm}$ ) and hypothalamic arcuate nucleus (ARC) (bregma -1.8 to -4.3 ) were sectioned at a $20 \mu \mathrm{m}$ thickness using a Cryostat (Leica CM1900; Leica Microsystems, Buffalo Grove, IL), then fixed with $4 \%$ paraformaldehyde then treated with $2 \mathrm{~N} \mathrm{HCl}$ solution for $30 \mathrm{~min}$ at $37{ }^{\circ} \mathrm{C}$, followed by a $10 \mathrm{~min}$ incubation with boric acid buffer to neutralize the acid, then washed in PBS. After permeabilization and blocking, sections were incubated with anti-BrdU monoclonal antibody (Sigma, St. Louis, MO; 1:500) overnight at $4{ }^{\circ} \mathrm{C}$, and then with the secondary antibody Alexa Fluor 488 donkey anti-mouse (Abcam, Cambridge, MA; 1:500) for $1 \mathrm{~h}$ at room temperature. Sections were mounted with a mounting medium containing 4',6-diamidino-2-phenylindole (DAPI) to counterstain nuclei (Invitrogen, Waltham, MA). BrdU positive cells were counted using ITCN (Image-based Tool for Counting Nuclei for Image), NIH, Bethesda).

\section{RNA extraction and real-time polymerase chain reaction}

Frontal cortex and hypothalamus were aseptically dissected, and total RNA was extracted from $30 \mathrm{mg}$ tissue samples using RNeasy Mini Kit (Qiagen, Valencia, CA). Total RNA in each sample was quantitated and assessed for quality using the NanoDrop-1000 version 3.7 (Thermo Scientific, Waltman, MA). A ratio of A260/A280 of $\sim 2.0$ was obtained for all RNA samples. One thousand nanograms per microliter of total RNA from each sample was converted to complementary DNA (cDNA) using high capacity cDNA reverse transcription kit (Applied Biosystems, Carlsbad, CA). RT-PCR was performed at $95{ }^{\circ} \mathrm{C}$ for 5 min followed by 40 cycles of $95{ }^{\circ} \mathrm{C}$ for $15 \mathrm{~s}, 60^{\circ} \mathrm{C}$ for $30 \mathrm{~s}$, and $72{ }^{\circ} \mathrm{C}$ for $40 \mathrm{~s}$ in Applied Biosystems 7500 Real-time PCR system (ABI, Carlsbad, CA). The relative quantity of a target mRNA was performed by real-time RT-PCR using SYBR Green (Applied Biosystems, Foster City, CA). Primers used are summarized in Table 2. Measurement of GAPDH and RPL-19 mRNA levels served as internal controls for all experiments. Amplification was performed for 1 cycle of a sequential incubation at $50{ }^{\circ} \mathrm{C}$ for $2 \mathrm{~min}$ and $95{ }^{\circ} \mathrm{C}$ for $5 \mathrm{~min}$, and subsequent 40 cycles of a consecutive incubation at $95{ }^{\circ} \mathrm{C}$ for $15 \mathrm{~s}, 60{ }^{\circ} \mathrm{C}$ for $30 \mathrm{~s}$, and $72{ }^{\circ} \mathrm{C}$ for $40 \mathrm{~s}$. The individual gene expression value was calculated after normalization to GAPDH and RPL-19.

\section{Statistical analysis}

Statistical analysis of data was performed using Graph Pad Prism software version 5.0 (LA Jolla, CA). Data were analyzed using unpaired student's $t$ test or one way ANOVA with Newman-Keuls post-hoc tests where
Table 2 List of primers used for Real-Time QPCR analysis

\begin{tabular}{|c|c|}
\hline Primers & Sequence \\
\hline Cycline E1 F & 5'- GACAGCTAGCGCGGTGTAG-3' \\
\hline Cycline E1 R & 5'-TTGGAACTCAGACCCGAAGC-3' \\
\hline $\mathrm{Cdk} 2 \mathrm{~F}$ & 5'-CTTTGCCGAAATGGTGACCC-3' \\
\hline Cdk2 R & 5'- CCCAGAGTCCGAAAGATCCG-3' \\
\hline NPAT F & 5'- CCTITTAAGGGCCACCACCTC-3' \\
\hline NPAT R & 5'- AAGGGTAAAGACGCGAGGAC-3' \\
\hline SLBP F & 5'- AGCTCTCCTTCAAACCACCG-3' \\
\hline SLBP R & 5'- ATGGCCTTCAGGCGTTGTAA-3' \\
\hline $\mathrm{H} 2 \mathrm{AF}$ & 5'- AAGCTCGTGCAAAAGCGAAG-3' \\
\hline $\mathrm{H} 2 \mathrm{AR}$ & 5'- CCTAATGAGGTTGGGGGTGG-3' \\
\hline $\mathrm{H} 3 \mathrm{~F}$ & 5'- CGTTGGAGGAGCTTCGTCTT-3' \\
\hline H3 R & 5'- TTGGTTCGGGCCATCTTCTC-3' \\
\hline $\mathrm{H} 4 \mathrm{~F}$ & 5'-GCAAGGTCTTGCGGGATAAC-3' \\
\hline H4 R & 5'- GCTCAGTGTAGGTGACTGCG-3' \\
\hline
\end{tabular}

$F$ forward primer, $R$ reverse primer, $c d k 2$ cyclin dependent kinase $2, N P A T$ $\underline{\text { nuclear }}$ protein ataxia-telangiectasia; SLBP: stem-loop binding protein

appropriate. All results are presented as standard error of the mean (SEM). $P<0.05$ was considered as significant.

\section{Results}

PAE altered the turnover rates of canonical histones and histone variants

To explore the effects of alcohol exposure on histone turnover in postnatal rat brain, we administered a milk diet containing $11.34 \%$ of ethanol $(2.5 \mathrm{~g} / \mathrm{kg}$ per day, alcohol-fed, AF) or an isocaloric liquid control diet (pair-fed, PF) to 2-day-old Sprague Dawley rat pups for 5 days. During the feeding, ${ }^{2} \mathrm{H}_{2} \mathrm{O}$ was added to the milk diet for continuous labeling of newly made proteins. Samples were then collected for determining the protein kinetics via LC/MS.

As expected, there is a change in the relative abundance of the isotopic peaks in animals following 5 days of chronic dosing with the ${ }^{2} \mathrm{H}_{2} \mathrm{O}$ tracer as compared to the spectra that is observed in control animals, which did not receive any ${ }^{2} \mathrm{H}_{2} \mathrm{O}$; there is a marked difference between the AF and PF groups (Fig. 1). Similar data sets were collected for the various histones that are discussed herein. The fractional synthesis rates (FSRs) are determined from the total change in isotopic labeling of the peptide product as outlined in the "Methods" section. It is important to note that the overall logic which is used here, including the data that are acquired, is virtually identical to that described by Zee et al. [41] with the exception of the shift in isotopic distribution. For example, since Zee et al. [41] administered a more highly substituted precursor (i.e., ${ }^{13} \mathrm{C}_{6}^{15} \mathrm{~N}_{2}$-lysine) in cultured HeLa cells, they observed a shift in a region of the mass spectra where there is less natural background [40]. 
Efforts by our group have focused on the use of ${ }^{2} \mathrm{H}_{2} \mathrm{O}$ for reasons noted earlier in regard to the ease of administration in chronic long-term in vivo studies. We also observe a change in the molecular weight (as shown by the shift in isotope distribution in Fig. 1); however, this occurs in a region of the mass spectra where there is more natural background labeling (this is corrected as part of the calculations).

To convert the data contained in Fig. 1 to kinetic rates, e.g., FSR and half-life, one follows a few basic calculations that are outlined in the "Methods" section. The first step involves a calculation of the total enrichment, i.e., subtract the background distribution observed in control animals. The second step is to sum the excess labeling and normalize that against the water labeling; this requires an additional constant factor which is derived from knowledge of the amino acid sequence and the expected equilibration of ${ }^{2} \mathrm{H}$ from body water with the respective amino acids [30,31]. These calculations yield an estimate of the FSR.

Our high-resolution accurate mass LC-MS analyses allowed us to identify several histone-derived peptides as well as measure the incorporation of ${ }^{2} \mathrm{H}$. First, we measured ${ }^{2} \mathrm{H}$ incorporation in the newly made replicationdependent canonical histones $\mathrm{H} 2 \mathrm{~A}, \mathrm{H} 2 \mathrm{~B}, \mathrm{H} 3$, and $\mathrm{H} 4$. These histones have long half-lives, and their synthesis is tightly linked to DNA replication [42, 43]. Figure 2 clearly shows that $\mathrm{H} 2 \mathrm{~A}$ followed by $\mathrm{H} 3$ has the highest FSR, reflecting faster turnover rates of these histones in both the brain regions studied, the frontal cortex $(F(3$,
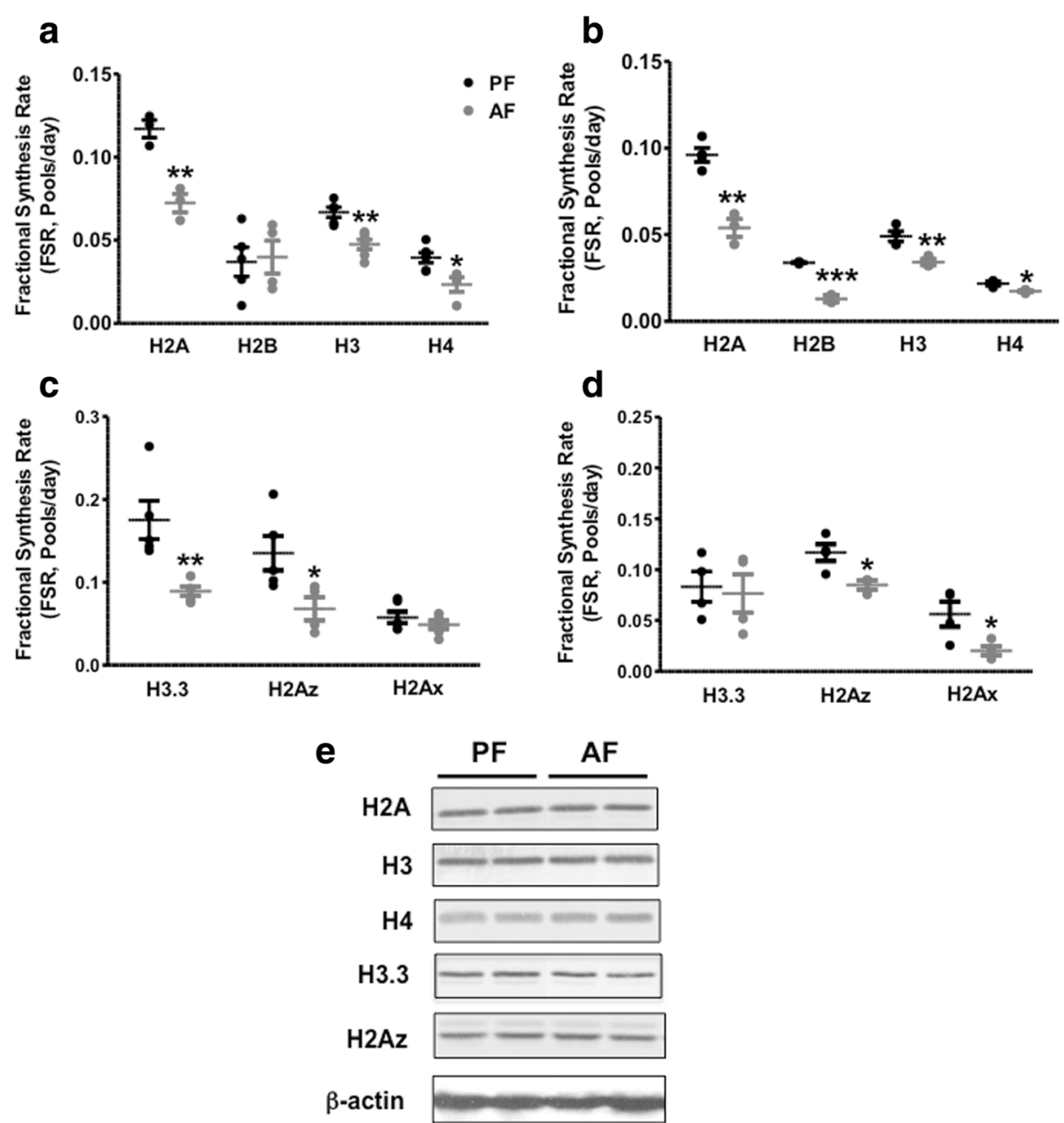

Fig. 2 Effects of PAE on the fractional synthesis of replication-dependent canonical histones and histone variants in frontal cortex and hypothalamus of developing rat brain. We measured the incorporation of ${ }^{2} \mathrm{H}$ in the canonical histone peptides H2A (vTIAQGGVLPNIQAVLLPkkTESHHk), H2B (iLLPGELAkHAVSEGTkAVTkYTSAK), H3 (kQLATkAAR), and H4 (gk GGkkGLGkGAkR) and histone variant peptides H3.3 (kSAPSTGGVkkPHR), H2Az (aTIAGGGGVIPHIH kSLIGkkGQQkTV), and H2Ax (kGHYAER) in frontal cortex (a, c) and hypothalamus (b, d) of 6-day-old rat pups following a 5-day alcohol feeding and administration of ${ }^{2} \mathrm{H}_{2} \mathrm{O}$. Histone Fractional Synthesis Rate (FSR) was calculated as described in the "Methods" section, and data are shown as mean $\pm \mathrm{SE}, n=5-8$ per group, ${ }^{*} p<0.05,{ }^{* *} p<0.01,{ }^{* * *} p<0.001$, AF vs PF. e Western-blot analysis of histone proteins in whole brain of PF and AF animals. The reference protein $\beta$-actin is also shown 
10) $=71.37, p<0.0001$, Fig. 2a) and the hypothalamus $(F(3,10)=124.8, p<0.0001$, Fig. 2b). Figure 2 also clearly shows that PAE significantly decreased the FSR of $\mathrm{H} 2 \mathrm{~A}, \mathrm{H} 2 \mathrm{~B}, \mathrm{H} 3$, and $\mathrm{H} 4$, reflecting a decrease in turnover rates and therefore an increase of the half-lives of these histones in the frontal cortex and the hypothalamus (Fig. 2, Table 3 and Additional file 4: Table S1).

We also measured the turnover rates of newly labeled replication-independent histone variants (i.e., H3.3, $\mathrm{H} 2 \mathrm{Az}$, and H2Ax). The data shown in Fig. 2c, d and Additional file 4: Table S1 indicates that the histone variant H3.3 has a faster turnover rate in the frontal cortex (Fig. 2c) than in the hypothalamus (Fig. 2d). PAE dramatically decreased H3.3 turnover rate in the frontal cortex with no significant change in the hypothalamus. The turnover rate of $\mathrm{H} 2 \mathrm{Az}$ was decreased in both brain regions; however, the turnover rate of $\mathrm{H} 2 \mathrm{Ax}$ was not affected in the frontal cortex but significantly decreased in the hypothalamus. These findings indicate that PAE differentially affects the turnover rates of replicationindependent histone variants and that differences exist between both brain regions studied.

In addition, we investigated whether these changes in histone turnover are associated with changes in histone abundance; western-blot analysis was used to determine the quantity of total histones in the whole brain of PF and AF animals. Figure 2e clearly shows that PAE had no effect on the abundance of $\mathrm{H} 2 \mathrm{~A}, \mathrm{H} 3, \mathrm{H} 4, \mathrm{H} 3.3$ and $\mathrm{H} 2 \mathrm{Az}$ histone proteins, suggesting that the total quantity of histones is not affected by PAE and that alcohol's effect is most likely altering the turnover and therefore the newly made histone pool.

\section{PAE altered the turnover rates of linker histone $\mathrm{H} 1$ and its variants}

As their name indicates, linker histones bind to the linker DNA located between two adjacent nucleosomes and provide an additional stabilizing effect on chromatin. We next explored the turnover rates of the linker histone $\mathrm{H} 1$ and its variants, H1.1, H1.4, and H1.5 (Fig. 3 and Additional file 4: Table S1). We found that the linker histone $\mathrm{H} 1$ and its variant $\mathrm{H} 1.1$ had a higher FSR in the frontal cortex than in the hypothalamus. Regardless of the brain region, H1.1 histone had the highest turnover than the other linker histones $(F(3,11)=15.02$, $p<0.0003$ in the frontal cortex, Fig. 3a; $F(3,10)=12.31$, $p<0.001$ in the hypothalamus and $3 \mathrm{~B})$. In addition, PAE dramatically decreased the FSR and therefore the turnover rates of $\mathrm{H} 1$ and $\mathrm{H} 1.1$ in the frontal cortex with no significant changes in $\mathrm{H} 1.4$ and $\mathrm{H} 1.5$ turnover rates (Fig. 3a). In the hypothalamus, however, the rates of all

Table 3 Summary of the effects of PAE on half-lives of histones in frontal cortex and hypothalamus of rat brain

\begin{tabular}{|c|c|c|c|c|}
\hline \multirow[b]{2}{*}{ Histone } & \multicolumn{2}{|c|}{ Half-life in frontal cortex (d) } & \multicolumn{2}{|c|}{ Half-life in Hypothalamus (d) } \\
\hline & $\overline{\mathrm{PF}}$ & $\mathrm{AF}$ & $\overline{\mathrm{PF}}$ & $\mathrm{AF}$ \\
\hline H2Aun & $5.9 \pm 0.3$ & $9.7 \pm 0.8^{* *}$ & $7.2 \pm 0.4$ & $13.1 \pm 1.3^{* *}$ \\
\hline H2AK120meK126ac & $6.9 \pm 1.1$ & $11.7 \pm 3.6$ & $6.8 \pm 0.5$ & $10.7 \pm 2.3^{* *}$ \\
\hline H2Bun & $27.4 \pm 8.9$ & $41.5 \pm 15.2$ & $20.5 \pm 0.2$ & $65.5 \pm 12.1^{* * *}$ \\
\hline H2BK9ac & $14.2 \pm 4.4$ & $12.8 \pm 5.8$ & $9.4 \pm 1.5^{\# \#}$ & $20.7 \pm 2.8^{* * \#}$ \\
\hline H3un & $11.0 \pm 0.9$ & $14.6 \pm 1.1^{* *}$ & $14.3 \pm 0.9$ & $20.5 \pm 1.0^{* *}$ \\
\hline $\mathrm{H} 3 \mathrm{~K} 1 \mathrm{ac}$ & $7.5 \pm 0.4^{\# \#}$ & $8.7 \pm 0.4^{\# \#}$ & $8.9 \pm 0.2^{\#}$ & $17.5 \pm 5.9^{*}$ \\
\hline H3K9 & $10.0 \pm 0.6$ & $20.2 \pm 2.9$ & $19.8 \pm 3.0$ & $33.2 \pm 1.7$ \\
\hline H3K9me2 & $25.2 \pm 6.7$ & $21.4 \pm 1.3$ & $18.2 \pm 2.8$ & $22.3 \pm 3.1$ \\
\hline H3K9me3 & $23.1 \pm 5.8$ & $46.1 \pm 15.8$ & $38.7 \pm 5.7^{\mathrm{a}}$ & $69.8 \pm 4^{* * *}$ \\
\hline H3K9ac & $6.4 \pm 0.4^{\#}$ & $12.1 \pm 3.3$ & $10.5 \pm 2.0^{\#}$ & $19.9 \pm 6.7$ \\
\hline H4un & $16.2 \pm 1.7$ & $29.8 \pm 6.3^{* *}$ & $28.4 \pm 3.4$ & $40.3 \pm 1.1^{*}$ \\
\hline H4K5acK9acK13ac & $8.2 \pm 0.7^{\# \#}$ & $8.5 \pm 0.1^{\# \# \#}$ & $11.5 \pm 2.9^{\#}$ & $14.8 \pm 2.6^{\#}$ \\
\hline $\mathrm{H} 1$ & $10.0 \pm 1.3$ & $20.4 \pm 5.9^{* * *}$ & $12.3 \pm 1.2$ & $19.8 \pm 1.2^{*}$ \\
\hline $\mathrm{H} 1.1$ & $3.9 \pm 0.7$ & $7.9 \pm 0.7^{*}$ & $5.7 \pm 0.7$ & $10.8 \pm 2.2^{*}$ \\
\hline $\mathrm{H} 1.4$ & $12.7 \pm 2.8$ & $13.9 \pm 1.5$ & $11.1 \pm 0.6$ & $18.9 \pm 0.9^{* * *}$ \\
\hline $\mathrm{H} 1.5$ & $11.3 \pm 1.8$ & $20.2 \pm 8.2$ & $10.1 \pm 0.6$ & $14.5 \pm 0.3^{*}$ \\
\hline H3.3 & $4.2 \pm 0.6$ & $7.8 \pm 0.5^{* *}$ & $9.3 \pm 2.0$ & $11.3 \pm 3.5$ \\
\hline $\mathrm{H} 2 \mathrm{Ax}$ & $12.1 \pm 1.6$ & $14.3 \pm 1.5$ & $15.1 \pm 5.0$ & $39.6 \pm 9.1^{*}$ \\
\hline $\mathrm{H} 2 \mathrm{Az}$ & $5.1 \pm 0.9$ & $8.6 \pm 2.0^{* *}$ & $6.0 \pm 0.5$ & $8.2 \pm 0.5^{*}$ \\
\hline
\end{tabular}

Half-lives are calculated from FSR data as described in the "Methods" section. $d$ day, Un unmodified, Ac: acetylated, me2 di-methylation, me3 tri-methylation. Data are shown as mean $\pm \mathrm{SE}, n=4$ per group, ${ }^{*} p<0.05,{ }^{* *} p<0.01,{ }^{* * *} p<0.001, \mathrm{AF}$ vs $\mathrm{PF}, \# p<0.05, \# \#<0.01, \# \# \# p<0.001 \mathrm{Nac}$ vs Ac 


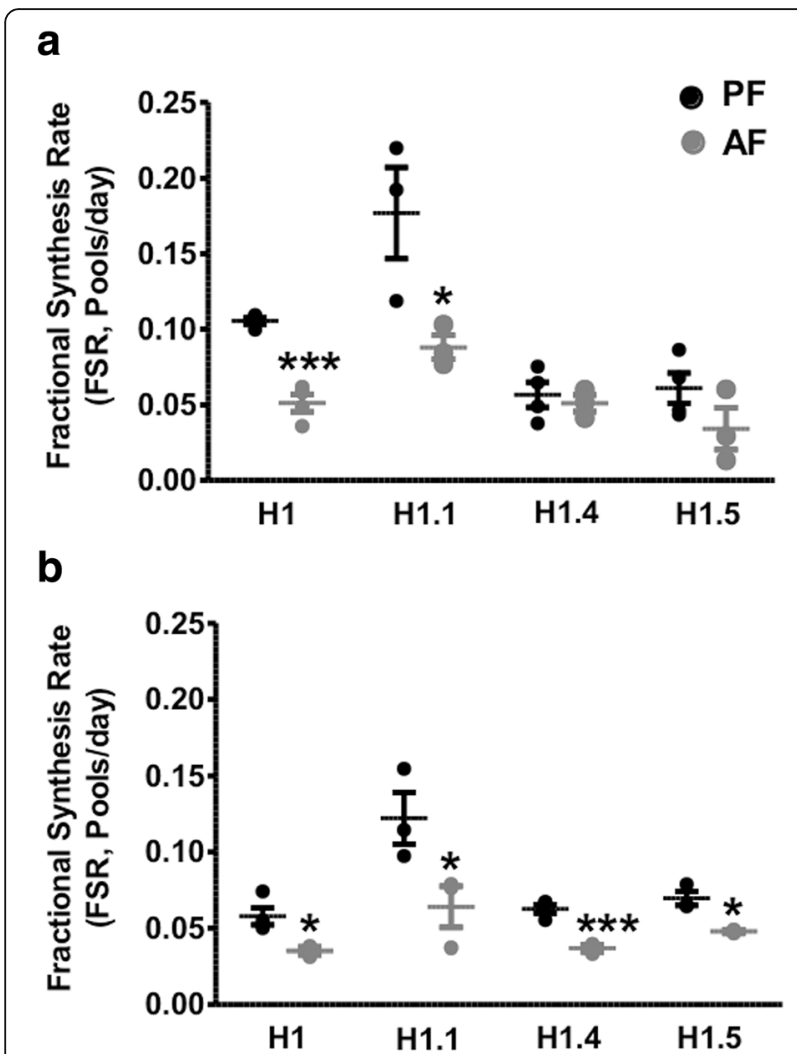

Fig. 3 Effects of PAE on the fractional synthesis of linker histone peptides in frontal cortex and hypothalamus of rat brain. We measured the incorporation of ${ }^{2} \mathrm{H}$ in the following histone variant peptides $\mathrm{H} 1$ (rAkAAkkSTDHPkYSDMIVAAIQAEkNR), H1.1 (SGVSLAALkkSLAAAGY DVEkNNSR), H1.4 (sGVSLAALkkSLAAAGYDVEkNNSR), and H1.5 (kATGPPVSELITkAVSASkER) in frontal cortex (a) and hypothalamus (b) of 6 days old rat pups following a 5-day alcohol feeding and administration of ${ }^{2} \mathrm{H}_{2} \mathrm{O}$. Histone Fractional Synthesis Rate (FSR) was calculated and data are shown as mean $\pm \mathrm{SE}, n=4$ per group, ${ }^{*} p<0.05,{ }^{* * *} p<0.001$, AF vs PF

linker histones were significantly decreased, although to a lesser extent than in the frontal cortex (Fig. 3b).

\section{PAE altered the turnover rates of modified histones}

To explore the rates of histone turnover as function of their PTMs, we identified acetylated and methylated peptides of the above aforementioned replication-dependent canonical histones. We determined the relative FSR of the newly labeled modified histone peptides, which then was contrasted to the FSR of the unmodified peptides (Figs. 4, 5, and 6 and Additional file 4: Table S1). Peptide sequences of modified and unmodified H2A, H2B, H3, and $\mathrm{H} 4$ analyzed in this study are shown in Table 1.

Figure 4 shows data that were generated from the frontal cortex and the hypothalamus examining the turnover of acetylated peptides identified as H2B, H3, and H4 histones. As reported by others [41, 44], our method confirms the findings that acetylated histones have a significantly faster turnover than the unmodified histones. We found that PAE significantly decreased the turnover rates of unmodified $\mathrm{H} 2 \mathrm{~B}, \mathrm{H} 3$, and $\mathrm{H} 4$ in the frontal cortex and the hypothalamus, but had no effect on the acetylated forms in the frontal cortex (Fig. 4a, c, and e) while it decreased the turnover rates of acetylated $\mathrm{H} 2 \mathrm{~B}, \mathrm{H} 3$, and $\mathrm{H} 4$ in the hypothalamus (Fig. 4b, d, and f). We were the first to identify a new H2A peptide that was double modified with a methyl group on lysine 120 and an acetyl group on lysine 126 (i.e., H2AK120meK126ac). H2AK120meK126ac has not been reported previously. We calculated the relative FSR of the newly labeled double modified $\mathrm{H} 2 \mathrm{~A}$ and compared its turnover rate to the unmodified $\mathrm{H} 2 \mathrm{~A}$ peptide. Interestingly, the turnover rate of H2AK120meK126ac was not significantly different from the unmodified peptide in both brain regions (Fig. 5 and Additional file 4: Table S1). PAE in a similar manner significantly decreased the turnover rates of unmodified as well as doubly modified H2A (Fig. 5 and Additional file 4: Table S1). Furthermore, the analysis of di- and tri-methylated histone $\mathrm{H} 3$ revealed that progressively methylated histones have slower turnover rates than the unmodified histones. Figure 6 and Additional file 4: Table S1 show that H3K9me3 had a slower turnover rate than $\mathrm{H} 3 \mathrm{~K} 9 \mathrm{me} 2$ and H3K9un in the hypothalamus (Fig. 6b). Interestingly, PAE decreased the turnover rates of H3K9un as well as H3K9me3 and had no significant effect on H3K9me2. Histone $\mathrm{H} 3$ was shown to be either methylated or acetylated on lysine K9. In this same set of samples, we were able to simultaneously identify an acetylated H3 on lysine 9 (i.e., H3K9ac). Consistent with the findings in Fig. 5, H3K9ac had a faster turnover than the unmodified peptide and the methylated peptides (H3K9me2 and H3K9me3), and in a similar manner was decreased by PAE in both brain regions studied $(F(3$, $8)=13.00, p<0.0019$ in the frontal cortex, Fig. 6a; $F(3$, $10)=10.99, p<0.0017$ in the hypothalamus, Fig 6b).

Since these types of studies generally assume that the kinetics under investigation are described by a single compartment model, and reflect a first-order process, then one can convert the FSR data into protein half-lives using the standard equation half-life $=\ln 2 /$ FSR [94]. Table 3 presents a comparative summary of the calculated half-lives of the different histone peptides identified in this study.

\section{PAE induces oxidative DNA damage}

Several studies including ours have shown that alcohol exposure induces ROS production and results in oxidative DNA damage. To investigate whether oxidative DNA damage is involved in the changes of histone turnover observed in response to PAE, we next measured the phosphorylation of histone $\mathrm{H} 2 \mathrm{Ax}$ on serine 139, referred to as $\gamma \mathrm{H} 2 \mathrm{Ax}$, an early marker of DNA damage. 


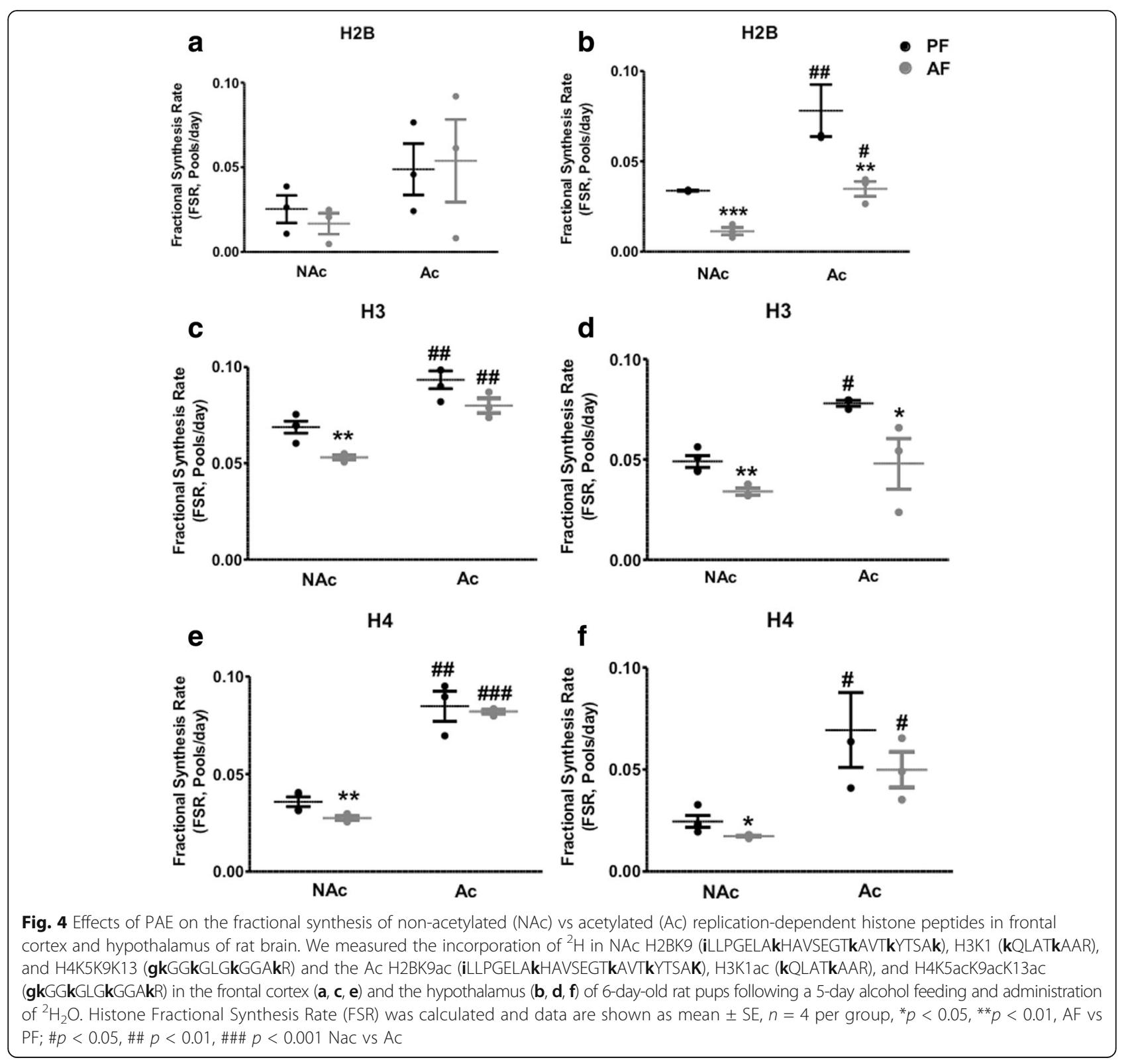

Figure 7 indicates that PAE significantly increased $\gamma \mathrm{H} 2 \mathrm{Ax}$ foci formation in the frontal cortex (Fig. 7a) and the hypothalamus (Fig. 7b) of AF rat pups compared to PF. To confirm these findings, we also measured the formation of 8-hydroxy 2 deoxyguanosine (8-OHdG), a known marker for DNA oxidative damage. Figure 7 shows that PAE significantly increased the formation of 8-OHdG in the frontal cortex and the hypothalamus (Fig. 7c) of AF animals compared to PF. To determine the role of free radicals in the PAE on oxidative DNA damage, we used the spin trap agent PBN. PBN treatment efficiently reduced the formation of $8-\mathrm{OHdG}$ in brain tissue from AF-PBN animals compared to AF animals (Fig. 7d).

\section{The effect of the free radical spin trap PBN on histone} turnover

We next investigated the effects of the spin trapping agent PBN on histone turnover. In this study, a subset of rat pups from each experimental group ( $\mathrm{PF}$ and $\mathrm{AF}$ ) was subjected to a subcutaneous injection of $100 \mathrm{mg} / \mathrm{Kg}$ body weight of PBN once a day. Histones were extracted from prefrontal cortex, digested and analyzed using LC-MS/MS. As shown in Fig. 8, PBN treatment did not inhibit the effects of PAE on $\mathrm{H} 3, \mathrm{H} 2 \mathrm{Az}$, or H2Ax turnover. However, PBN administration significantly increased $\mathrm{H} 3.3$ and $\mathrm{H} 4$ turnover rates in AF-PBN animals compared to AF alone. These findings suggest that the free radical spin trap PBN efficiently prevented the effects of PAE on the turnover of $\mathrm{H} 4$ and $\mathrm{H} 3.3$ 


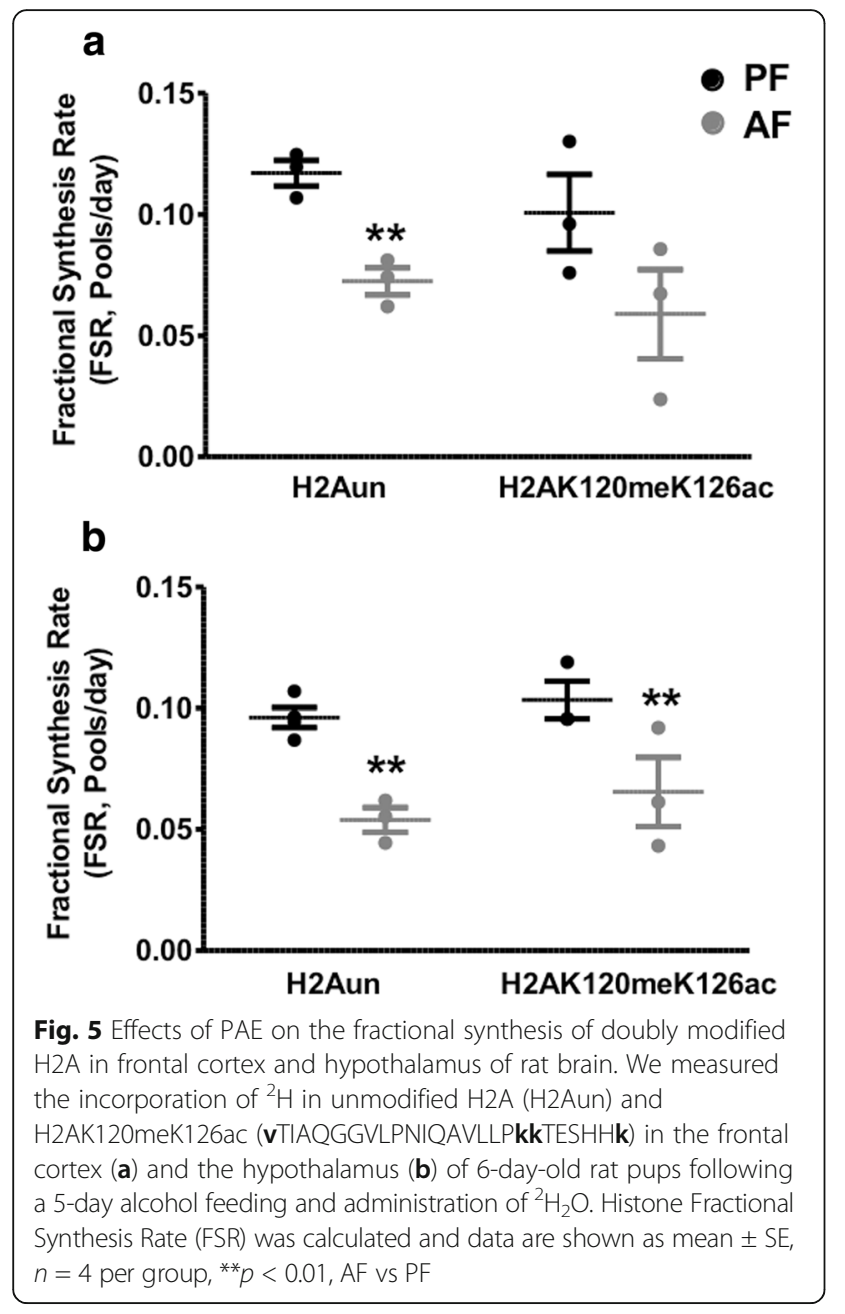

histones, but not on $\mathrm{H} 3$ and $\mathrm{H} 2 \mathrm{Az}$, indicating a differential effect of this reagent on histones in the brain.

\section{PAE changed cell proliferation and the expression of cell cycle and histone synthesis genes}

The PAE-mediated decrease in turnover rates of the replication-dependent canonical histones prompted us to further explore some of the possible underlying molecular mechanisms involved. Since the bulk of canonical histones are synthesized during the S-phase of the cell cycle, we investigated the effects of PAE on cell proliferation using BrdU incorporation and fluorescence microscopy. The number of BrdU-positive cells was counted, and as shown in Fig. 9, PAE significantly decreased the number of proliferating cells in frontal cortex (Fig. 9a, c) and hypothalamus (Fig. 9b, c) of AF animals compared to PF. However, the decrease in cell proliferation was more pronounced in the frontal cortex compared to the hypothalamic region $(p<0.0003)$ (Fig. 9).

It is well established that the synthesis of canonical histones is tightly coupled to DNA synthesis during the
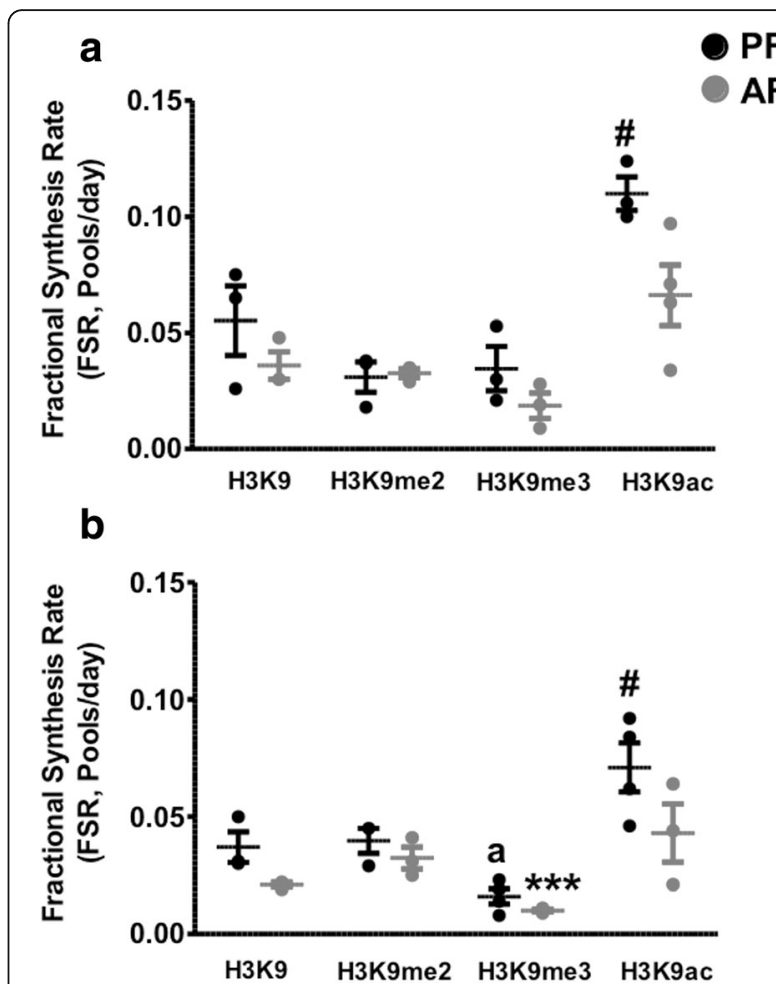

Fig. 6 Effects of PAE on the fractional synthesis of $\mathrm{H} 3 \mathrm{~K} 9$ and its modified peptides in frontal cortex and hypothalamus of rat brain. We measured the incorporation of ${ }^{2} \mathrm{H}$ in the histone $\mathrm{H} 3$ peptide H3K9 (kSTGGKAPR) and its di-methylated (H3K9me2), tri-methylated (H3K9me3), and acetylated (H3K9ac) isoforms on lysine 9, in frontal cortex (a) and hypothalamus (b) of 6-day-old rat pups following a 5day alcohol feeding and administration of ${ }^{2} \mathrm{H}_{2} \mathrm{O}$. Histone Fractional Synthesis Rate (FSR) was calculated and data are shown as mean $\pm \mathrm{SE}$, $n=4$ per group, ${ }^{* * *} p<0.001$, AF vs PF, \#p $<0.05$, modified vs unmodified peptides, a $p<0.05$, H3K9me3 vs H3K9 and H3K9me2

S-phase of the cell cycle. To elucidate some of the molecular mechanisms underlying the decrease in cell proliferation, we next investigated the effects of PAE on the expression of cell cycle genes. PAE significantly decreased the gene expression of cyclin E in frontal cortex (Fig. 10a) and had no significant effect in the hypothalamus (Fig. 10b) of AF rat pups compared to PF. In addition, PAE had no significant effect on cdk2 gene expression (Fig. 10a, b). While PAE dramatically decreased NPAT gene expression in the frontal cortex and the hypothalamus of AF animals, there was no significant change in the expression of SLBP (Fig. 10c, d). Next, we examined the impact of these changes on histone mRNA expression. Figure 10 indicates that PAE had no significant effect on histone mRNA levels in frontal cortex (Fig. 10e) or hypothalamus (Fig. 10f) of AF rat pups compared to PF.

\section{Discussion}

The molecular mechanisms underlying the adverse effects of alcohol exposure on fetal brain remain poorly understood. 


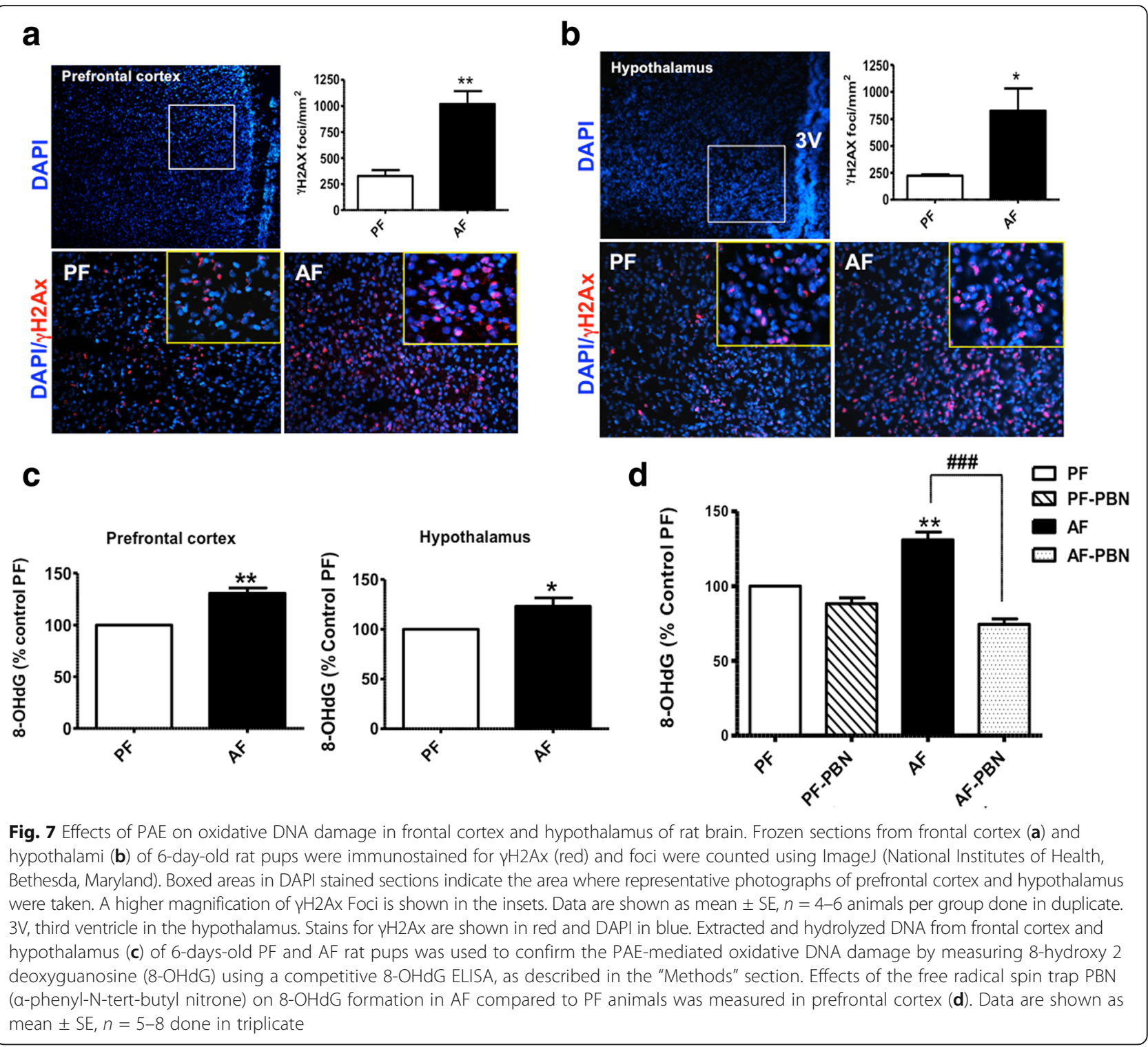

However, it is becoming clear that epigenetic alterations resulting in changes in gene expression play a key role in the development of FASD. DNA methylation, histone modifications, and non-coding RNA have been suggested as molecular mediators of the adverse effects of FAE [21, 22, 45]. However, one has to recognize that we are still far from having a clear understanding of the complex molecular epigenetic processes involved in FASD. For example, most neuroepigenetic studies have focused on DNA methylation and histone PTMs as the primary mechanisms affecting chromatin structure and gene expression; little is known about the temporal dynamics and turnover of histones. Recently, it has become clear that nucleosomal histone turnover is critical for cell-specific gene transcription, DNA damage repair and recovery, neuronal plasticity, and brain development [46-48]. Herein we have examined whether
PAE affects turnover of histone proteins in postnatal rat brain.

Histone turnover has been studied in vivo using ${ }^{14} \mathrm{C}$ and ${ }^{3} \mathrm{H}$-radiolabeled amino acids [29, 49]; in cases where the proteins of interest have long half-lives, this approach is complicated since one may need to continuously administer the labeled precursor. Since ${ }^{2} \mathrm{H}$ in body water will rapidly and continuously generate ${ }^{2} \mathrm{H}$-labeled amino acids and since body water has a relatively long half-life, our ${ }^{2} \mathrm{H}$ method circumvents a major technical challenge in studies of in vivo kinetics. The analysis of ${ }^{2} \mathrm{H}$-labeled proteins is achieved using standard mass spectrometry-based proteome analyses, which facilitates the identification of specific analytes in complex mixtures [31]. For example, one can examine the kinetics of unmodified as well as modified histones. 


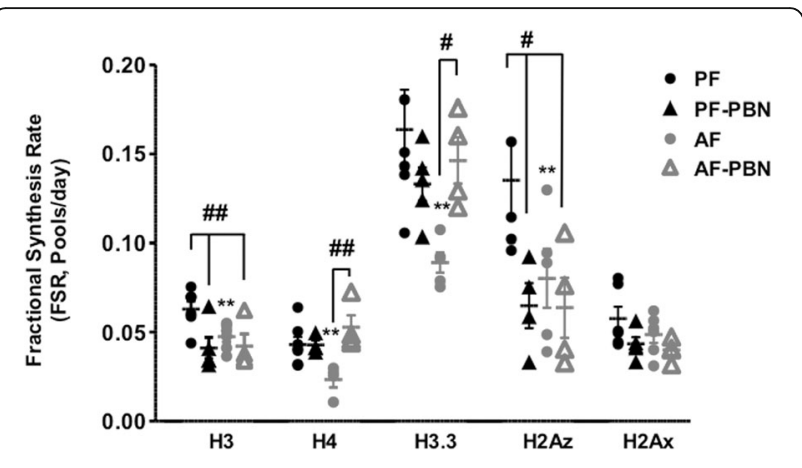

Fig. 8 Effects of PBN on fractional synthesis of histones in frontal cortex of PF and AF rat pups. We measured the incorporation of ${ }^{2} \mathrm{H}$ in the canonical histone peptides $\mathrm{H} 3$ (kQLATkAAR), H4 ( $\mathbf{k}$ kGGkGLGkGGAkR) and histone variant peptides H3.3 (kSAPSTGGVkkPHR), H2AZ (aTIAGGGVIPHIHkSLIGkkGQQkTV), and H2Ax (kGHYAER) in frontal cortex of 6-day-old rat pups following a 5-day alcohol feeding and administration of ${ }^{2} \mathrm{H}_{2} \mathrm{O}$ and $100 \mathrm{mg} / \mathrm{Kg}$ of the free radical spin trap PBN (a-phenyl-N-tert-butyl nitrone). Histone Fractional Synthesis Rate (FSR) was calculated as described in the "Methods" section, and data are shown as mean $\pm \mathrm{SE}, n=5-8$ per

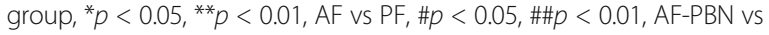
$\mathrm{PF}, \mathrm{AF}$ and $\mathrm{PF}-\mathrm{PBN}$

The LC-MS approach used herein is similar to that reported by Zee et al. [41], with an obvious difference being the strategy for labeling proteins (note that this difference simply reflects the constraints of working in cell-based vs in vivo models). As shown (Figs. 2, 3, 4, 5, and 6, Table 3 and Additional file 4: Table S1), we were able to determine the kinetics of several histones in vivo in rat developing brain. Analogous to Zee et al. [41], we were also able to quantify the kinetics of some modified histones.

We report that the replication-dependent canonical histones, $\mathrm{H} 2 \mathrm{~A}, \mathrm{H} 2 \mathrm{~B}, \mathrm{H} 3$, and $\mathrm{H} 4$, which were shown to be stable and have long half-lives [42, 43], incorporated ${ }^{2} \mathrm{H}$-labeling during the 5 days exposure of rat pups to ${ }^{2} \mathrm{H}$-water. This indicates that newly synthesized canonical histones are deposited into chromatin. In addition, $\mathrm{H} 2 \mathrm{~A}$ had the fastest turnover rate compared to $\mathrm{H} 3$, $\mathrm{H} 2 \mathrm{~B}$, and $\mathrm{H} 4$, consistent with previous studies $[41,50]$. Several studies have shown that differences in nucleosomal histone turnover are reflective of differences in epigenetic functions and chromatin localizations. For example, histones in promoter regions of active genes have higher turnovers than those in coding regions [51, 52]. We show that PAE decreases turnover rates of canonical histones in frontal cortex and hypothalamus. This indicates that in addition to the effects on DNA and histone epigenetic marks [15, 21, 23-25], alcohol alters histone turnover, which might compromise normal processes of gene expression and cellular functions.

Histone variants, particularly of $\mathrm{H} 2 \mathrm{~A}$ and $\mathrm{H} 3$, are expressed throughout the cell cycle and replace DNA replication-dependent canonical histones. Histone variants have distinct amino acid sequences that can affect the chromatin landscape and nucleosomal dynamics and therefore play critical roles in transcription regulation and other cellular processes such as DNA repair response $[53,54]$. Studies have shown that in cortical neurons, the replication-independent histone variants H3.3, H2A.2, and H2Ax replace their canonical counterparts with postnatal age and cellular differentiation [55]. These histone variants are constitutively expressed in a promoter-dependent manner independently of DNA replication. Among the two H3.3 genes identified in the brain ( $h 3 f 3 a$ and $h 3 f 3 b)$, the expression of $h 3 f 3 b$ is highly responsive to neuronal stimuli such as glutamatergic receptor activation, GABA receptor inhibition, neurotrophic signaling (e.g., BDNF) and membrane depolarization $[46,56]$. Furthermore, deletion of H2Ax or mutation of its Ser139 impairs the recruitment of DNA damage repair proteins, such as BRCA1 and 53BP1 [26, 27]. Most importantly, a HIRAmediated H3.3 deposition in the DNA damage pathway is also crucial to the maintenance of chromatin integrity and the restoration of the transcriptional activity upon completion of DNA damage repair [28]. In addition, H2A.Z depletion causes an increased sensitivity to ionizing radiation and genomic instability through prevention of BRCA1 binding to sites of DNA damage, indicating that H2A.Z exchange is important for DNA repair by creating an open chromatin structure that facilitates subsequent binding of repair factors [57]. We next sought to analyze turnover of the histone variants $\mathrm{H} 3.3, \mathrm{H} 2 \mathrm{Az}$, and $\mathrm{H} 2 \mathrm{Ax}$ and we show similar findings. However, differential regulations were observed between frontal cortex and hypothalamus. H3.3 had a higher turnover in the frontal cortex, and PAE decreased this turnover rate by $\sim 50 \%$, with no effect in the hypothalamus. PAE also significantly decreased the turnover of $\mathrm{H} 2 \mathrm{Az}$. In contrast, the turnover rates of $\mathrm{H} 2 \mathrm{Az}$ and $\mathrm{H} 2 \mathrm{Ax}$ were significantly decreased in the hypothalamus. This defines a critical aspect of the differential effects of alcohol on distinct brain regions as previously documented $[11,58]$ and might reflect differential effects of this PAE-mediated reduction in $\mathrm{H} 3.3, \mathrm{H} 2 \mathrm{Az}$, and $\mathrm{H} 2 \mathrm{Ax}$ turnovers on chromatin structure and therefore might influence gene expression.

Linker histones connect nucleosomes and provide additional stability to DNA [59], and more likely contribute to regulation of gene expression. We report that among the replication-dependent histone linkers, H1.1 had the fastest turnover. Studies have suggested that linker histones exhibit preferential genomic distributions and different chromatin affinities [60,61], which could explain the differences in turnover rates. Histones H1, H1.4, and H1.5 are expressed in all cell types, whereas H1.1 is specifically expressed in testis, spleen, thymus, lymphocytes, and neuronal cells [62], suggesting that linker 

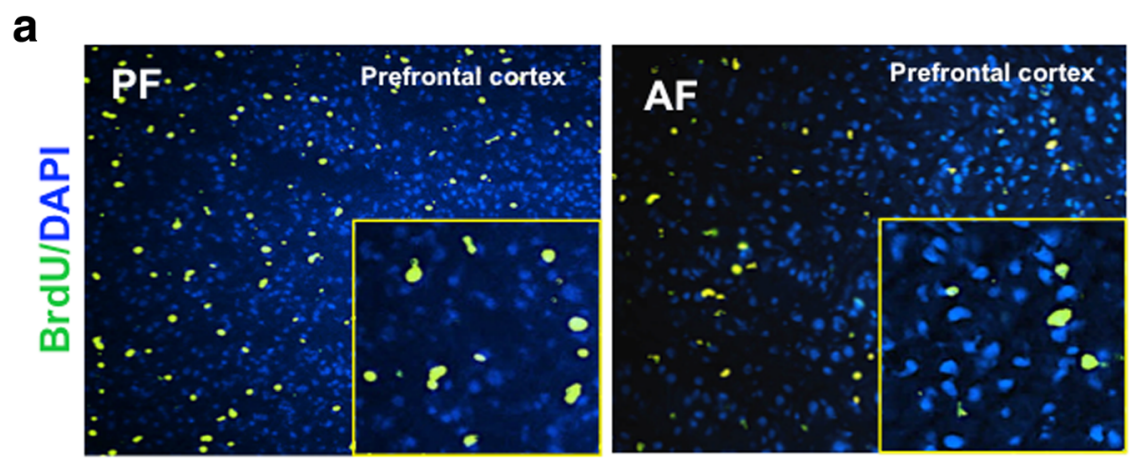

\section{b}

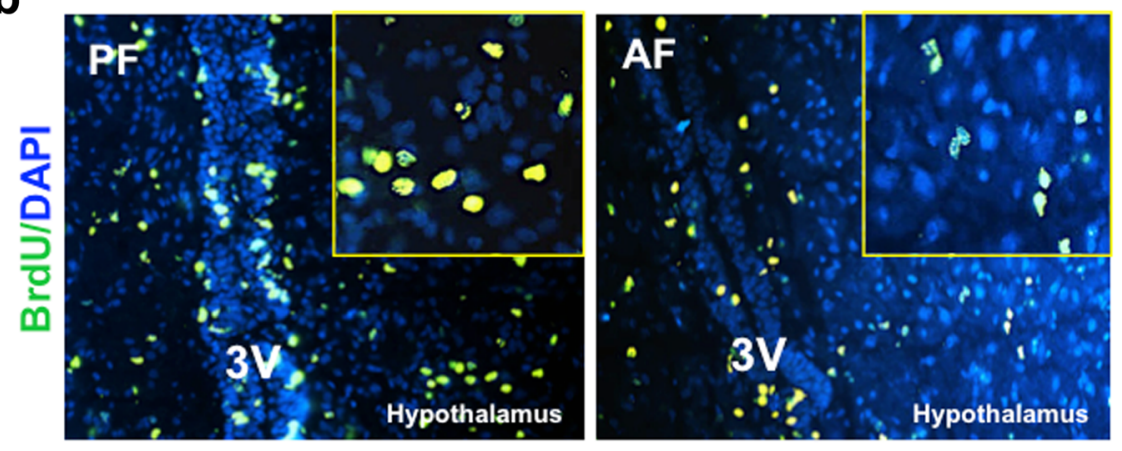

C

Prefrontal cortex

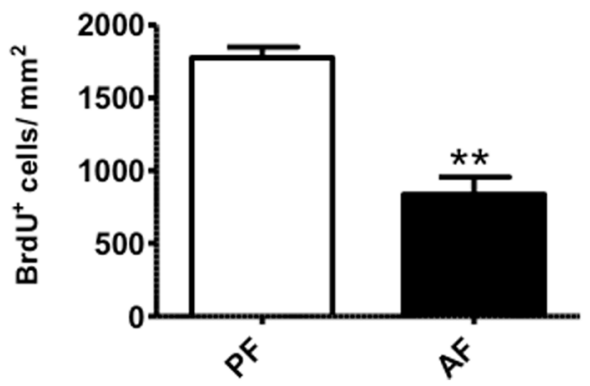

Hypothalamus

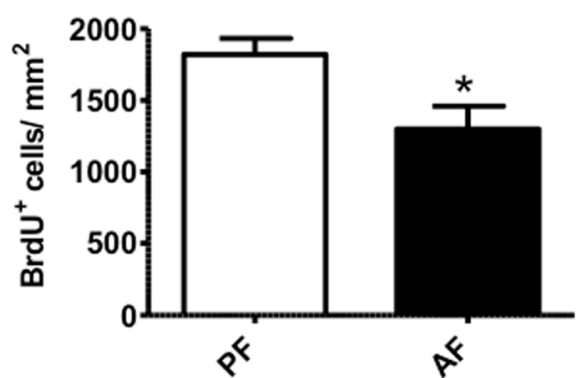

Fig. 9 Effects of PAE on BrdU incorporation and cell proliferation in frontal cortex and hypothalamus of rat brain. Representative immunofluorescence images, at 20X, visualized using the fluorescence microscope Nikon Eclipse 2000 (Nikon, Melville, NY) are shown. Higher magnification of BrdU signal is shown in insets. BrdU positive cells were counted in frontal cortex (a) and hypothalamus (b) of PF and AF animals using ImageJ (National Institutes of Health) and quantifications are shown in (c). Data are shown as mean $\pm S E, n=4-6$ animals per group done in duplicates, ${ }^{*} p<0.05$, *** $p<0.001$, AF vs PF

histones might have different tissue-specific functions. We show that PAE decreases $\mathrm{H} 1$ and $\mathrm{H} 1.1$ turnovers in the frontal cortex, and H1, H1.1, H1.4, and H1.5 turnovers in the hypothalamus, suggesting differential effects of PAE on linker histones.

In addition, turnover rates of histones vary depending on their PTMs. For example, acetylated histones have faster turnovers than unmodified histones [41, 44], which correlate with localization in the genome. Acetylated histones are predominantly assembled into promoters and enhancers of active genes, whereas repressive methylated histones are present on inactive chromatin regions. We report that acetylated $\mathrm{H} 2 \mathrm{~B}, \mathrm{H} 3$, and $\mathrm{H} 4$ have faster turnovers than unmodified histones. H3K9ac had a significantly higher turnover than the unmodified (H3K9) and the methylated peptides (H3K9me2 and H3K9me3). H3K9ac was shown to be associated with promoters of active genes [63]. Most interestingly, we are the first to report a new doubly modified H2A, H2AK120meK126ac, which had a similar turnover rate as the unmodified $\mathrm{H} 2 \mathrm{~A}$. Of note, 


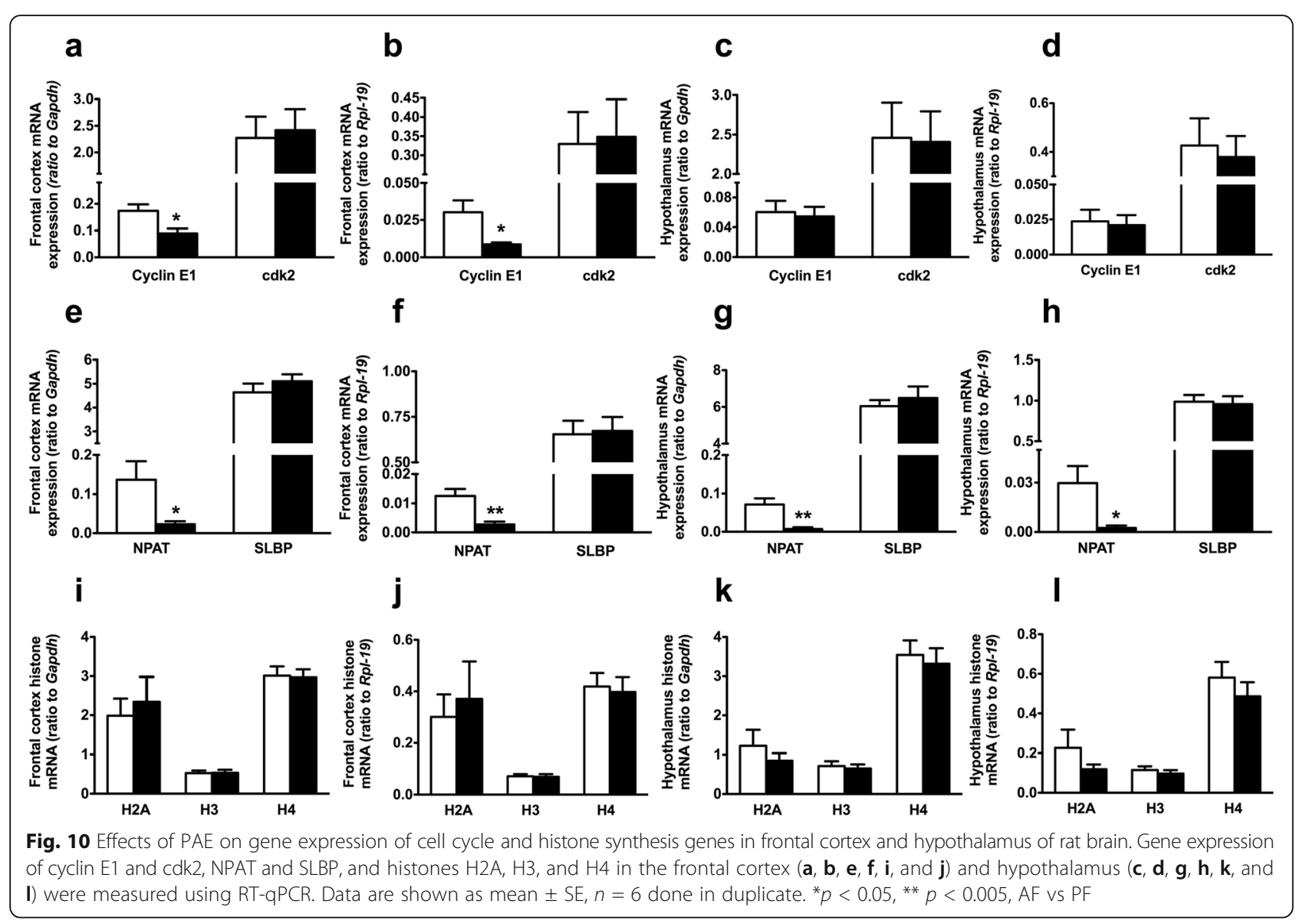

H2AK120meK126ac has not been reported previously and its function is unknown. Studies have suggested that bivalent modifications might exhibit antagonistic actions towards each other, such as in the case of developmental genes, where bivalent modification might have an important role in silencing these genes and keeping them poised for activation [41, 64]. All these findings show that PAE decreases histone turnover regardless of their PTMs. We do not present data on the turnover and recycling of modifications; rather, our findings provide novel information on alcohol's effects on histone turnover. This implies an effect of alcohol on newly made histone incorporation and assembly into chromatin.

The interplay between histone variants and chromatin remodeling and accessibility of DNA repair machinery suggests the importance of a sustained availability of histone molecules to ensure that the DNA lesions are faithfully repaired and transcription is resumed for cell function recovery. Herein, we demonstrate that PAE, as previously reported [20], increased $\gamma \mathrm{H} 2 \mathrm{Ax}$ and 8-OHdG formation indicative of DNA oxidative damage. Interestingly, although the administration of the free radical spin trap PBN efficiently prevented the formation of 8-OHdG in alcohol-fed animals, it did not prevent the effects of
PAE on the turnover of all histones studied. Most interestingly, PBN administration almost fully prevented the decrease observed in H3.3 turnover by PAE. Considering the importance of this histone variant in brain development and neuronal plasticity $[46,47]$, as well as in DNA repair and recovery [28], we believe these findings are intriguing. Further studies are necessary to evaluate the impact of these findings.

We also show that these effects of PAE on histone turnover were associated with decreased cell proliferation. Proper DNA replication during the S-phase of the cell cycle requires that core histones $\mathrm{H} 2 \mathrm{~A}, \mathrm{H} 2 \mathrm{~B}, \mathrm{H} 3$, and H4 be simultaneously synthesized $[65,66]$. Disturbances in DNA or histone synthesis can result in defects in chromosome segregation [67], be deleterious for cell growth [68] and increase DNA damage sensitivity and cytotoxicity [20, 69]. Furthermore, alcohol exposure is known to induce growth arrest through altered expression of cell cycle proteins, inhibition of proliferation, and increased DNA fragmentation [70, 71]. We show that PAE decreased cyclin E1 and NPAT mRNA expression. No significant changes in $\mathrm{cdk} 2$, SLBP, or the canonical histone mRNA levels were observed. Replication-dependent histone mRNAs are non-polyadenylated mRNAs with a 
conserved 3' stem-loop end structure that is recognized by SLBP, a histone mRNA stabilizing factor, and cleaved by U7 snRNP complex, responsible for the inhibition of the translation of replication-dependent histone mRNAs at the end of the S-phase [72]. Levels of polyadenylated histone mRNAs are low during proliferation [73] and increase during terminal differentiation [74]. Interference with chromatin structure results in the production of polyadenylated histone mRNAs [75]; whether these polyadenylated histone mRNAs are translated into histones is unclear. We suggest that although PAE had no effect on levels of histone mRNA, one cannot exclude the possibility that PAE might interfere with 3 '-end processing and/or affect post-translational and chromatin deposition processes of histone proteins.

\section{Conclusions}

These findings demonstrate our ability to measure histone turnover in rat brain using ${ }^{2} \mathrm{H}_{2} \mathrm{O}$-labeling and mass-spectrometry. We report that PAE induces a global but differential decrease in histone turnover rates in frontal cortex and hypothalamus. Alterations in histone turnover might interfere with histone deposition, chromatin stability, and cell-specific gene expression. We provide novel insights into the effects of PAE on histone turnover in the brain, which might play an important role in the development of the neurological disorders associated with FASD. Further studies exploring cellspecific and function-specific effects of alcohol exposure on histone turnover are necessary for understanding the molecular basis of epigenetic alterations underlying the development of FASD.

\section{Additional files}

Additional file 1: Figure S2. $\mathrm{yH} 2 \mathrm{Ax}$ immunostaining in the frontal cortex of $A D$ and PF control animals. Representative immunofluorescence images, at 20X, visualized using the fluorescence microscope Nikon Eclipse 2000 (Nikon, Melville, NY) are shown. $\gamma H 2 \mathrm{Ax}$ foci (red) were counted in the frontal cortex of AD and PF animals using ImageJ (National Institutes of Health). Data are shown as mean $\pm \mathrm{SE}, n=4-6$ animals per group done in duplicate. (TIFF 2702 kb)

Additional file 2: Figure S3. BrdU incorporation and cell proliferation in the frontal cortex of $A D$ and PF control animals. Representative immunofluorescence images, at 20X, visualized using the fluorescence microscope Nikon Eclipse 2000 (Nikon, Melville, NY) are shown. BrdU positive cells (green) were counted in the frontal cortex of AD and PF animals using ImageJ (National Institutes of Health). Data are shown as mean $\pm S E, n=4-6$ animals per group done in duplicates. (TIFF 2702 kb)

Additional file 3: Figure S1. MS/MS spectra for rat histone $\mathrm{H} 2 \mathrm{~A}$ peptide (VTIAQGGVLPNIQAVLLPkkTESHHk) (A) and histone H3 peptide (kQLATKAAR) (B). Several sequence specific N-terminal (b) and C-terminal (y) ions are identified in these spectra, and these ions confirm the peptides and protein identification. Please note all N-termini and all Lysine residues were propionylated by chemical derivatization. (TIFF $2702 \mathrm{~kb}$ )

Additional file 4: Table S1. Summary of the effects of PAE on FSR of histones in frontal cortex and hypothalamus of rat brain. FSR is calculated as described in the "Methods" section. Un: unmodified; Ac: acetylated; me2: di-methylation; me3: tri-methylation. Data are shown as mean $\pm \mathrm{SE}, n=5-8$ per group, ${ }^{*} p<0.05,{ }^{* *} p<0.01,{ }^{* * *} p<0.001$, AF vs PF, \#p $<0.05$, \#\#p $<$ 0.01 , \#\#\# $<0.001 \mathrm{Nac}$ vs Ac. (DOCX $16 \mathrm{~kb})$

\section{Abbreviations}

8-OHdG: 7,8-Dihydro-8-oxo-2'-deoxyguanosine; BAC: Blood alcohol concentration; BDNF: Brain-derived neurotrophic factors; FASD: Fetal alcohol spectrum disorders; FSR: Fractional synthesis rate; LC-MS: Liquid chromatography mass-spectrometry; NPAT: Nuclear protein ataxiatelangiectasia; PAE: Postnatal alcohol exposure; PTM: Posttranslational modification; ROS: Reactive-oxygen species; SLBP: Stem-loop binding protein

\section{Acknowledgements}

We thank Shaima Jabbar and Courtney Stevens for technical assistance. This work is partly supported by a National Institute of Health grant supported by $\mathrm{NIH}$ grants R37AA08757 and R21AA024641 to DKS.

\section{Availability of data and materials}

All data generated and analyzed during this study is included in this manuscript and in Additional files.

\section{Authors' contributions}

NR conceived and designed the study, reviewed the literature, and wrote the paper. TK, LL, and BW did sample preparation and analysis with LC-MS. NR and SP analyzed the data. DS helped in designing the study and edited the manuscript. All authors read and approved the final manuscript.

Ethics approval and consent to participate

Not applicable.

\section{Consent for publication}

Not applicable.

\section{Competing interest}

We have no competing interest to disclose.

\section{Publisher's Note}

Springer Nature remains neutral with regard to jurisdictional claims in published maps and institutional affiliations.

\section{Author details}

${ }^{1}$ Department of Animal Sciences, Rutgers Endocrine Research Program, Rutgers, the State University of New Jersey, 67 Poultry Farm Lane, New Brunswick, NJ 08901, USA. ²Department of Research Core Services, Lerner Research Institute, Cleveland Clinic, Cleveland, OH 44106, USA. ${ }^{3}$ Department of Pharmaceutical Sciences, Northeast Ohio Medical University, Rootstown, $\mathrm{OH} 44272$, USA. ${ }^{4}$ Cardiometabolic Disease, Merck \& Co., Inc, Kenilworth, NJ, USA.

Received: 15 April 2017 Accepted: 4 October 2017

Published online: 23 October 2017

\section{References}

1. Riley EP, McGee CL. Fetal alcohol spectrum disorders: an overview with emphasis on changes in brain and behavior. Exp Biol Med (Maywood). 2005;230:357-65.

2. Astley SJ, Aylward EH, Olson HC, Kerns K, Brooks A, Coggins TE, Davies J, Dorn S, Gendler B, Jirikowic T, Kraegel P, Maravilla K, Richards T. Magnetic resonance imaging outcomes from a comprehensive magnetic resonance study of children with fetal alcohol spectrum disorders. Alcohol Clin Exp Res. 2009;33:1671-89.

3. Norman AL, Crocker N, Mattson SN, Riley EP. Neuroimaging and fetal alcohol spectrum disorders. Dev Disabil Res Rev. 2009;15:209-17.

4. Olney JW. New insights and new issues in developmental neurotoxicology. Neurotoxicology. 2002;23:659-68.

5. Li Z, Lin H, Zhu Y, Wang M, Luo J. Disruption of cell cycle kinetics and cyclin-dependent kinase system by ethanol in cultured cerebellar granule progenitors. Brain Res Dev Brain Res. 2001;132:47-58. 
6. Siegenthaler JA, Miller MW. Transforming growth factor beta1 modulates cell migration in rat cortex: effects of ethanol. Cereb Cortex. 2004;14:791-802.

7. Miller DB, Bartke A, O'Callaghan JP. Increased glial fibrillary acidic protein (GFAP) levels in the brains of transgenic mice expressing the bovine growth hormone (bGH) gene. Exp Gerontol. 1995;30:383-400.

8. Moulder KL, Fu T, Melbostad H, Cormier RJ, Isenberg KE, Zorumski CF, Mennerick S. Ethanol-induced death of postnatal hippocampal neurons. Neurobiol Dis. 2002;10:396-409.

9. Jacobs JS, Miller MW. Proliferation and death of cultured fetal neocortical neurons: effects of ethanol on the dynamics of cell growth. J Neurocytol. 2001;30:391-401.

10. Light KE, Belcher SM, Pierce DR. Time course and manner of Purkinje neuron death following a single ethanol exposure on postnatal day 4 in the developing rat. Neuroscience. 2002;114:327-37.

11. Maier SE, Miller JA, Blackwell JM, West JR. Fetal alcohol exposure and temporal vulnerability: regional differences in cell loss as a function of the timing of binge-like alcohol exposure during brain development. Alcohol Clin Exp Res. 1999;23:726-34.

12. Sarkar DK, Kuhn P, Marano J, Chen C, Boyadjieva N. Alcohol exposure during the developmental period induces beta-endorphin neuronal death and causes alteration in the opioid control of stress axis function. Endocrinology. 2007;148:2828-34.

13. Boyadjieva NI, Sarkar DK. Cyclic adenosine monophosphate and brainderived neurotrophic factor decreased oxidative stress and apoptosis in developing hypothalamic neuronal cells: role of microglia. Alcohol Clin Exp Res. 2013;37:1370-9.

14. Boyadjieva NI, Sarkar DK. Microglia play a role in ethanol-induced oxidative stress and apoptosis in developing hypothalamic neurons. Alcohol Clin Exp Res. 2013;37:252-62.

15. Gangisetty O, Bekdash R, Maglakelidze G, Sarkar DK. Fetal alcohol exposure alters proopiomelanocortin gene expression and hypothalamic-pituitaryadrenal axis function via increasing MeCP2 expression in the hypothalamus. PLoS One. 2014;9:e113228.

16. Brooks PJ. Brain atrophy and neuronal loss in alcoholism: a role for DNA damage? Neurochem Int. 2000;37:403-12.

17. Rulten SL, Hodder E, Ripley TL, Stephens DN, Mayne LV. Alcohol induces DNA damage and the Fanconi anemia D2 protein implicating FANCD2 in the DNA damage response pathways in brain. Alcohol Clin Exp Res. 2008; 32:1186-96.

18. Lamarche F, Gonthier B, Signorini N, Eysseric H, Barret L. Acute exposure of cultured neurones to ethanol results in reversible DNA single-strand breaks; whereas chronic exposure causes loss of cell viability. Alcohol Alcohol. 2003; 38:550-8.

19. Wells PG, McCallum GP, Chen CS, Henderson JT, Lee CJ, Perstin J, Preston TJ, Wiley $\mathrm{M}$, Wong AW. Oxidative stress in developmental origins of disease: teratogenesis, neurodevelopmental deficits, and cancer. Toxicol Sci. 2009;108:4-18.

20. Kruman II, Henderson Gl, Bergeson SE. DNA damage and neurotoxicity of chronic alcohol abuse. Exp Biol Med (Maywood). 2012;237:740-7.

21. Haycock PC. Fetal alcohol spectrum disorders: the epigenetic perspective. Biol Reprod. 2009;81:607-17.

22. Haycock PC, Ramsay M. Exposure of mouse embryos to ethanol during preimplantation development: effect on DNA methylation in the h19 imprinting control region. Biol Reprod. 2009;81:618-27.

23. Garro AJ, McBeth DL, Lima V, Lieber CS. Ethanol consumption inhibits fetal DNA methylation in mice: implications for the fetal alcohol syndrome. Alcohol Clin Exp Res. 1991;15:395-8.

24. Govorko D, Bekdash RA, Zhang C, Sarkar DK. Male germline transmits fetal alcohol adverse effect on hypothalamic proopiomelanocortin gene across generations. Biol Psychiatry. 2012;72:378-88.

25. Bekdash RA, Zhang C, Sarkar DK. Gestational choline supplementation normalized fetal alcohol-induced alterations in histone modifications, DNA methylation, and proopiomelanocortin (POMC) gene expression in betaendorphin-producing POMC neurons of the hypothalamus. Alcohol Clin Exp Res. 2013:37:1133-42.

26. Celeste A, Petersen S, Romanienko PJ, Fernandez-Capetillo O, Chen HT, Sedelnikova OA, Reina-San-Martin B, Coppola V, Meffre E, Difilippantonio MJ, Redon C, Pilch DR, Olaru A, Eckhaus M, Camerini-Otero RD, Tessarollo L, Livak F, Manova K, Bonner WM, Nussenzweig MC, Nussenzweig A. Genomic instability in mice lacking histone H2AX. Science. 2002;296:922-7.

27. Bassing $\mathrm{CH}$, Chua KF, Sekiquchi J, Suh H, Whitlow SR, Fleming JC, Monroe BC, Ciccone DN, Yan C, Vlasakova K, Livingston DM, Ferguson
DO, Scully R, Alt FW. Increased ionizing radiation sensitivity and genomic instability in the absence of histone H2AX. Proc Natl Acad Sci U S A. 2002;99:8173-8.

28. Adam S, Polo SE, Almouzni G. Transcription recovery after DNA damage requires chromatin priming by the H3.3 histone chaperone HIRA. Cell. 2013;155:94-106.

29. Mannironi C, Rossi V, Biondi A, Ubezio P, Giudici G, Masera G, D'Incalci M. Comparison of histone variant synthesis in human lymphocytic leukemia cells and in normal lymphocytes. Cancer Res. 1988;48:3670-5.

30. Rachdaoui N, Austin L, Kramer E, Previs MJ, Anderson VE, Kasumov T, Previs SF. Measuring proteome dynamics in vivo: as easy as adding water? Mol Cell Proteomics. 2009;8:2653-63.

31. Kasumov T, Ilchenko S, Li L, Rachdaoui N, Sadygov RG, Willard B, McCullough AJ, Previs S. Measuring protein synthesis using metabolic (2)H labeling, high-resolution mass spectrometry, and an algorithm. Anal Biochem. 2011;412:47-55.

32. Li L, Willard B, Rachdaoui N, Kirwan JP, Sadygov RG, Stanley WC, Previs S, McCullough AJ, Kasumov T. Plasma proteome dynamics: analysis of lipoproteins and acute phase response proteins with $2 \mathrm{H} 2 \mathrm{O}$ metabolic labeling. Mol Cell Proteomics. 2012;11:M111 014209.

33. Kasumov T, Dabkowski ER, Shekar KC, Li L, Ribeiro RF Jr, Walsh K, Previs SF, Sadygov RG, Willard B, Stanley WC. Assessment of cardiac proteome dynamics with heavy water: slower protein synthesis rates in interfibrillar than subsarcolemmal mitochondria. Am J Physiol Heart Circ Physiol. 2013; 304:H1201-14.

34. Commerford SL, Carsten AL, Cronkite EP. Histone turnover within nonproliferating cells. Proc Natl Acad Sci U S A. 1982;79:1163-5.

35. Fernandez CA, Des Rosiers C, Previs SF, David F, Brunengraber H. Correction of $13 \mathrm{C}$ mass isotopomer distributions for natural stable isotope abundance. J Mass Spectrom. 1996;31:255-62.

36. Ramachandra R, Subramanian T. Atlas of the Neonatal Rat Brain. CRC Press, Taylor \& Francis Group. 2011

37. Shechter $\mathrm{D}$, Dormann HL, Allis CD, Hake SB. Extraction, purification and analysis of histones. Nat Protoc. 2007;2:1445-57.

38. Lin S, Garcia BA. Examining histone posttranslational modification patterns by high-resolution mass spectrometry. Methods Enzymol. 2012;512:3-28.

39. Evertts AG, Zee BM, Dimaggio PA, Gonzales-Cope M, Coller HA, Garcia BA. Quantitative dynamics of the link between cellular metabolism and histone acetylation. J Biol Chem. 2013;288:12142-51.

40. Shah V, Herath K, Previs SF, Hubbard BK, Roddy TP. Headspace analyses of acetone: a rapid method for measuring the $2 \mathrm{H}$-labeling of water. Anal Biochem. 2010:404:235-7.

41. Zee BM, Levin RS, Dimaggio PA, Garcia BA. Global turnover of histone posttranslational modifications and variants in human cells. Epigenetics Chromatin. 2010;3:22.

42. Commerford SL, Carsten AL, Cronkite EP. Histone turnover within nonproliferating cells. Proc Natl Acad Sci. 1982;79:1163-1165.

43. Commerford SL, Carsten AL, Cronkite EP. The turnover of tritium in cell nuclei, chromatin, DNA, and histone. Radiat Res. 1982;92:521-529.

44. Rufiange A, Jacques PE, Bhat W, Robert F, Nourani A. Genome-wide replicationindependent histone $\mathrm{H} 3$ exchange occurs predominantly at promoters and implicates H3 K56 acetylation and Asf1. Mol Cell. 2007;27:393-405.

45. Kobor MS, Weinberg J. Focus on: epigenetics and fetal alcohol spectrum disorders. Alcohol Res Health. 2011;34:29-37.

46. Maze I, Wenderski W, Noh KM, Bagot RC, Tzavaras N, Purushothaman I, Elsasser SJ, Guo Y, lonete C, Hurd YL, Tamminga CA, Halene T, Farrelly L, Soshnev AA, Wen D, Rafii S, Birtwistle MR, Akbarian S, Buchholz BA, Blitzer RD, Nestler EJ, Yuan ZF, Garcia BA, Shen L, Molina H, Allis CD. Critical role of histone turnover in neuronal transcription and plasticity. Neuron. 2015;87:77-94.

47. Wenderski W, Maze I. Histone turnover and chromatin accessibility: critical mediators of neurological development, plasticity, and disease. BioEssays. 2016;38:410-9.

48. Polo SE. Reshaping chromatin after DNA damage: the choreography of histone proteins. J Mol Biol. 2015;427:626-36.

49. Bondy SC. The synthesis and decay of histone fractions and of deoxyribonucleic acid in the developing avian brain. Biochem J. 1971;123:465-9.

50. Bosch A, Suau P. Changes in core histone variant composition in differentiating neurons: the roles of differential turnover and synthesis rates. Eur J Cell Biol. 1995;68:220-5. 
51. Kraushaar DC, Jin W, Maunakea A, Abraham B, Ha M, Zhao K. Genome-wide incorporation dynamics reveal distinct categories of turnover for the histone variant H3.3. Genome Biol. 2013;14:R121.

52. Chen P, Wang Y, Li G. Dynamics of histone variant $\mathrm{H} 3.3$ and its coregulation with H2A.Z at enhancers and promoters. Nucleus. 2014;5:21-7.

53. Weber $\mathrm{CM}$, Henikoff $\mathrm{S}$. Histone variants: dynamic punctuation in transcription. Genes Dev. 2014;28:672-82.

54. Soria G, Polo SE, Almouzni G. Prime, repair, restore: the active role of chromatin in the DNA damage response. Mol Cell. 2012;46:722-34.

55. Pina $B$, Suau $P$. Changes in histones $\mathrm{H} 2 \mathrm{~A}$ and $\mathrm{H} 3$ variant composition in differentiating and mature rat brain cortical neurons. Dev Biol. 1987:123:51-8.

56. Madabhushi R, Gao F, Pfenning AR, Pan L, Yamakawa S, Seo J, Rueda R, Phan TX, Yamakawa H, Pao PC, Stott RT, Gjoneska E, Nott A, Cho S, Kellis M, Tsai LH. Activity-induced DNA breaks govern the expression of neuronal early-response genes. Cell. 2015;161:1592-605.

57. Xu Y, Ayrapetov MK, Xu C, Gursoy-Yuzugullu O, Hu Y, Price BD. Histone H2A. Z controls a critical chromatin remodeling step required for DNA doublestrand break repair. Mol Cell. 2012;48:723-33.

58. Topper LA, Baculis BC, Valenzuela CF. Exposure of neonatal rats to alcohol has differential effects on neuroinflammation and neuronal survival in the cerebellum and hippocampus. J Neuroinflammation. 2015;12:160.

59. Bednar J, Horowitz RA, Grigoryev SA, Carruthers LM, Hansen JC, Koster AJ, Woodcock CL. Nucleosomes, linker DNA, and linker histone form a unique structural motif that directs the higher-order folding and compaction of chromatin. Proc Natl Acad Sci U S A. 1998;95:14173-8.

60. Orrego M, Ponte I, Roque A, Buschati N, Mora X, Suau P. Differential affinity of mammalian histone $\mathrm{H} 1$ somatic subtypes for DNA and chromatin. BMC Biol. 2007:5:22.

61. Izzo A, Kamieniarz-Gdula K, Ramirez F, Noureen N, Kind J, Manke T, van Steensel B, Schneider R. The genomic landscape of the somatic linker histone subtypes H1.1 to H1.5 in human cells. Cell Rep. 2013;3:2142-54.

62. Happel N, Doenecke D. Histone $\mathrm{H} 1$ and its isoforms: contribution to chromatin structure and function. Gene. 2009;431:1-12

63. Karmodiya K, Krebs AR, Oulad-Abdelghani M, Kimura H, Tora L. H3K9 and H3K14 acetylation co-occur at many gene regulatory elements, while H3K14ac marks a subset of inactive inducible promoters in mouse embryonic stem cells. BMC Genomics. 2012;13:424

64. Bernstein BE, Mikkelsen TS, Xie X, Kamal M, Huebert DJ, Cuff J, Fry B, Meissner A, Wernig M, Plath K, Jaenisch R, Wagschal A, Feil R, Schreiber SL, Lander ES. A bivalent chromatin structure marks key developmental genes in embryonic stem cells. Cell. 2006;125:315-26.

65. Heintz N, Sive HL, Roeder RG. Regulation of human histone gene expression: kinetics of accumulation and changes in the rate of synthesis and in the half-lives of individual histone mRNAs during the HeLa cell cycle. Mol Cell Biol. 1983:3:539-50.

66. Morillo-Huesca M, Maya D, Munoz-Centeno MC, Singh RK, Oreal V, Reddy GU, Liang D, Geli V, Gunjan A, Chavez S. FACT prevents the accumulation of free histones evicted from transcribed chromatin and a subsequent cell cycle delay in G1. PLoS Genet. 2010;6:e1000964.

67. Singh RK, Kabbaj MH, Paik J, Gunjan A. Histone levels are regulated by phosphorylation and ubiquitylation-dependent proteolysis. Nat Cell Biol. 2009:11:925-33.

68. Han M, Chang M, Kim UJ, Grunstein M. Histone H2B repression causes cellcycle-specific arrest in yeast: effects on chromosomal segregation, replication, and transcription. Cell. 1987;48:589-97.

69. Olney JW, Ishimaru MJ, Bittigau P, Ikonomidou C. Ethanol-induced apoptotic neurodegeneration in the developing brain. Apoptosis. 2000:5:515-21.

70. Luo J, Miller MW. Growth factor-mediated neural proliferation: target of ethanol toxicity. Brain Res Brain Res Rev. 1998;27:157-67.

71. Anthony B, Zhou FC, Ogawa T, Goodlett CR, Ruiz J. Alcohol exposure alters cell cycle and apoptotic events during early neurulation. Alcohol Alcohol. 2008;43:261-73.

72. Marzluff WF, Wagner EJ, Duronio RJ. Metabolism and regulation of canonical histone mRNAs: life without a poly(A) tail. Nat Rev Genet. 2008;9:843-54.

73. Narita T, Yung TM, Yamamoto J, Tsuboi Y, Tanabe H, Tanaka K, Yamaguchi $Y$, Handa H. NELF interacts with CBC and participates in $3^{\prime}$ end processing of replication-dependent histone mRNAs. Mol Cell. 2007:26:349-65.
74. Collart D, Ramsey-Ewing A, Bortell R, Lian J, Stein J, Stein G. Isolation and characterization of a cDNA from a human histone $\mathrm{H} 2 \mathrm{~B}$ gene which is reciprocally expressed in relation to replication-dependent $\mathrm{H} 2 \mathrm{~B}$ histone genes during HL60 cell differentiation. Biochemistry. 1991;30:1610-7.

75. Pirngruber J, Johnsen SA. Induced G1 cell-cycle arrest controls replicationdependent histone mRNA $3^{\prime}$ end processing through p21, NPAT and CDK9. Oncogene. 2010;29:2853-63.

\section{Submit your next manuscript to BioMed Central and we will help you at every step:}

- We accept pre-submission inquiries

- Our selector tool helps you to find the most relevant journal

- We provide round the clock customer support

- Convenient online submission

- Thorough peer review

- Inclusion in PubMed and all major indexing services

- Maximum visibility for your research

Submit your manuscript at www.biomedcentral.com/submit
Biomed Central 